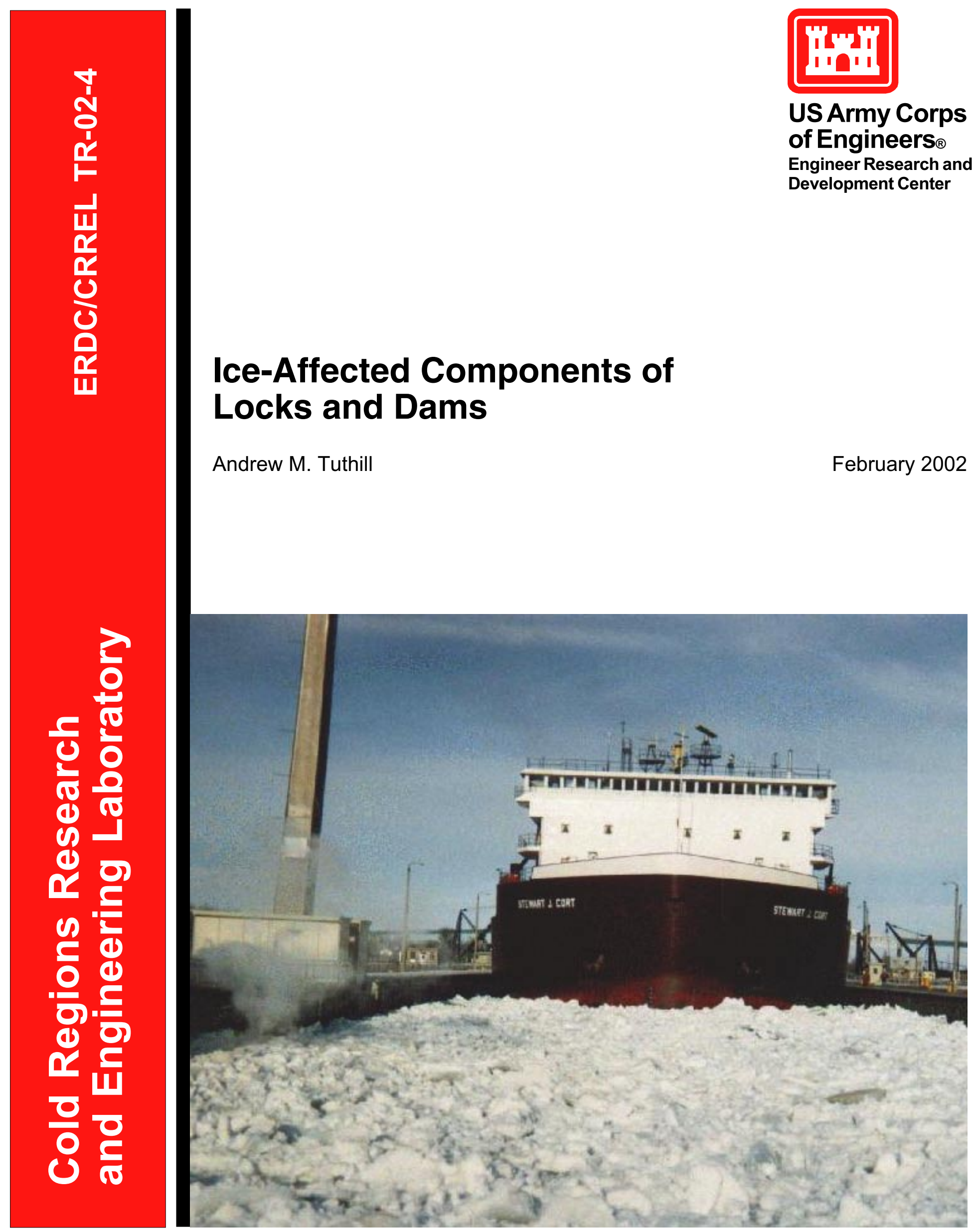


Abstract: Ice plagues the operation and maintenance of many U.S. Army Corps of Engineers locks and dams. Because these structures vary greatly in age, geographical setting, and design, their performance in ice also varies. This report describes the ice problems related to specific project components such as the lock approaches, miter gates, lock walls, and dam spillway gates. Post-construction solutions such as high-flow bubblers and heat deicing methods are also described. The report provides a one-source overview of the important ice problems faced by operators of Corps projects, available ice management solutions, and areas where improvements are most needed.

COVER: Vessel Stewart J. Cort in the Poe Lock at Sault Ste. Marie, Michigan, under heavy ice conditions, April 1996. Photo courtesy of Allen Jewell.

How to get copies of ERDC technical publications:

Department of Defense personnel and contractors may order reports through the Defense Technical Information Center:

DTIC-BR SUITE 0944

8725 JOHN J KINGMAN RD

FT BELVOIR VA 22060-6218

Telephone (800) 225-3842

E-mail help@dtic.mil msorders@dtic.mil

WWW http://www.dtic.mil/

All others may order reports through the National Technical Information Service:

NTIS

5285 PORT ROYAL RD

SPRINGFIELD VA 22161

Telephone (703) 487-4650

(703) 487-4639 (TDD for the hearing-impaired)

E-mail_orders@ntis.fedworld.gov

WWW http://www.ntis.gov/index.html

For information on all aspects of the Engineer Research and Development Center, visit our World

Wide Web site:

http://www.erdc.usace.army.mil 


\section{Technical Report ERDC/CRREL TR-02-4}

\section{Ice-Affected Components of Locks and Dams}

Andrew M. Tuthill

February 2002 


\section{PREFACE}

This report was prepared by Andrew M. Tuthill, Research Hydraulic Engineer, Ice Engineering Group, RS/GIS/Water Resources Branch, U.S. Army Engineer Research and Development Center (ERDC), Cold Regions Research and Engineering Laboratory (CRREL), Hanover, New Hampshire.

Funding for this research was provided by Civil Works work unit 33283, Winter Operation and Maintenance of Corps Structures. The author thanks the many people at Corps projects and districts who contributed to this effort.

This publication reflects the personal views of the author and does not suggest or reflect the policy, practices, programs, or doctrine of the U.S. Army or Government of the United States. The contents of this report are not to be used for advertising or promotional purposes. Citation of brand names does not constitute an official endorsement or approval of the use of such commercial products. 


\section{CONTENTS}

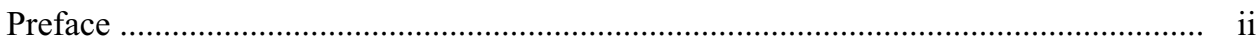

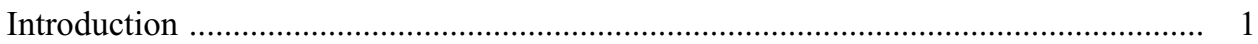

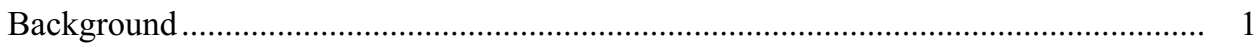

Ice-affected components of locks .......................................................................... 2

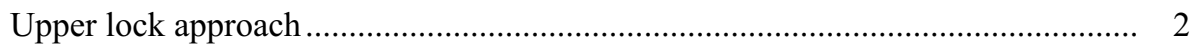

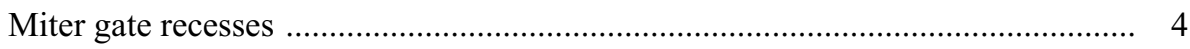

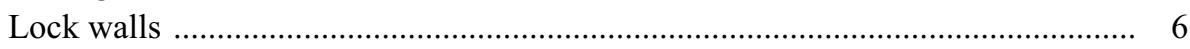

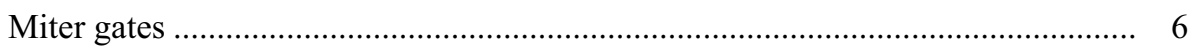

Submergible lift gates and emergency bulkheads ........................................... 8

Lock sill heights and brash ice beneath barges ..................................................... 10

Guidewalls, guardwalls, and mooring cells ..................................................... 10

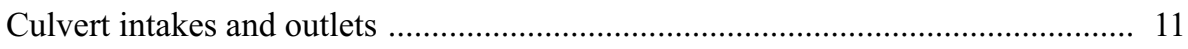

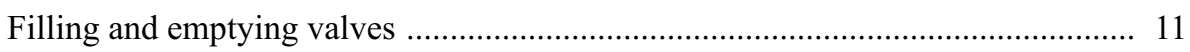

Ice congestion of lock chambers ................................................................ 12

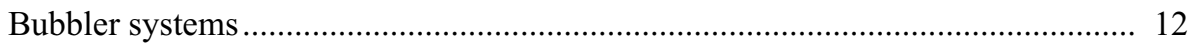

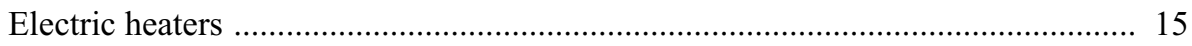

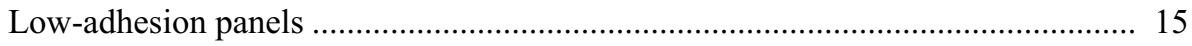

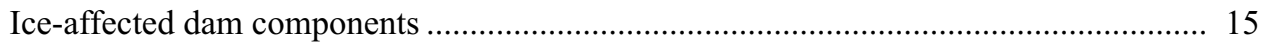

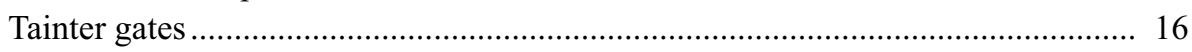

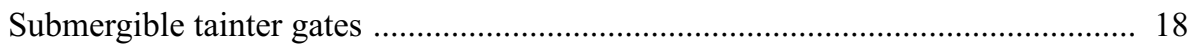

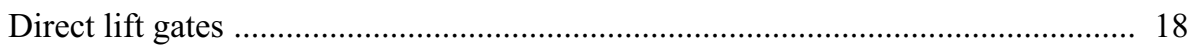

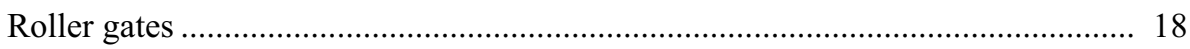

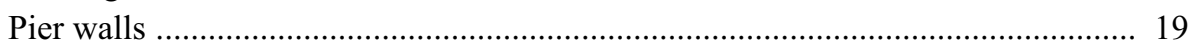

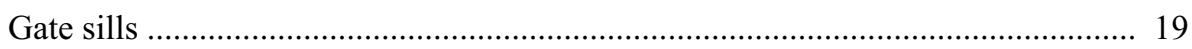

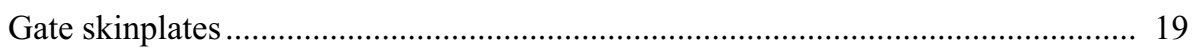

Downstream bed protection ................................................................... 19

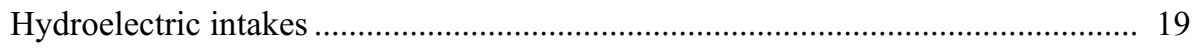

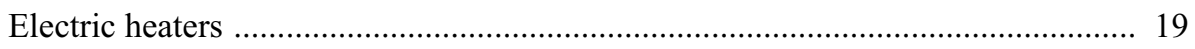

Steam heat systems

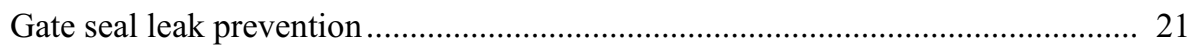

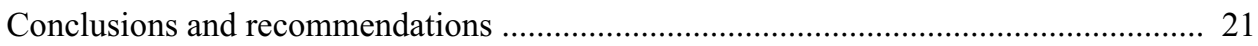

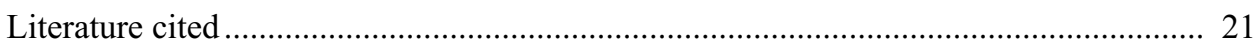

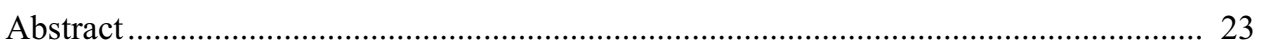

\section{ILLUSTRATIONS}

Figure

1. Relative severity of ice problems at Corps locks ............................................. 2

2. Relative severity of ice problems at Corps dams ............................................ 2

3. Ice accumulation in the upper approach at Lock and Dam 21 on the upper Mississippi River

4. Mel Price Lock and Dam on the Mississippi River at Alton, Illinois

5. Brash ice in the miter gate recess ............................................................. 5

6. Clearing brash ice from the gate recess with a pike pole at the Soo Locks ....... 5

7. Ice collars in the gate recess and on the lock wall ........................................... 6

8. Copolymer coating at the Soo Locks .............................................................. 7

9. Icing of the miter gate trusswork .................................................................... 7 
10. Miter at Lock 24 on the upper Mississippi with widely spaced structural members on the upstream side

11. Skimming ice over emergency bulkheads at New Cumberland Lock

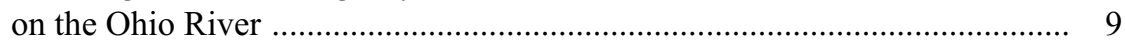

12. Submergible lift gate at Mel Price Lock ..................................................... 10

13. Drift pass in the river guardwall being widened at Lock and Dam 25 on the upper Mississippi

14. Le Grange Lock and Dam on the Illinois River

15. Ice flushing manifolds at the Poe Lock, Sault Ste. Marie, Michigan

16. Plan view of a high-flow bubbler system

17. Gate recess flusher at Starved Rock Lock ............ 14

18. Lower sill curtain at Starved Rock Lock 14

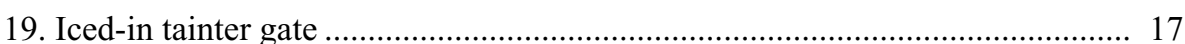

20. Submergible gate at Marseilles Dam ...................................................... 17

21. Direct lift gate at Montgomery Dam ……................................................... 18

22. Steam manifold at Starved Rock Dam 20

\section{TABLES}

Table

1. Ice-affected lock components and related issues ............................................. 3

2. Ice-affected dam components and related issues .............................................. 15 


\title{
Ice-Affected Components of Locks and Dams
}

\author{
ANDREW M. TUTHILL
}

\section{INTRODUCTION}

The U.S. Army Corps of Engineers operates over 75 locks and dams on ice-affected rivers in the United States. Most of these projects lie on the upper Mississippi, the Illinois, and the Ohio River systems and were constructed during the period from 1930 to present, and more than half are over 50 years old. Because of variations in age, location, and the physical requirements of the structure, a wide variety of designs exists for the various project components. This report describes typical Corps lock and dam designs and their components and assesses how well they perform in the river ice environment.

\section{BACKGROUND}

Winter operation of locks and dams has been the subject of considerable research over the last few decades. In a Corps-wide survey by Zufelt and Calkins (1985) 75 locks and dams reported ice problems with various project components, including

- Brash ice* congestion in the upper lock approach

- Brash ice in the miter gate recess

- Icing of lock and miter gate recess walls

- Icing of miter gate trusswork and operating machinery

- Freezing-in of floating mooring bits and vertical check pins.

Reported ice problems with dam components included

- Brash ice congestion upstream of dam gates

*Brash ice is an accumulation of broken ice pieces, ranging in diameter from inches to feet. Tow traffic breaks up the solid ice cover in the pools above the locks to form brash ice.
- Freezing-in of tainter gates because of leaking seals and spray icing

- Frozen side seals

- Frozen-in trunnion arms

- Ice formation on turbine intakes.

Haynes et al. (1993) conducted a comprehensive survey of ice problems at 171 Corps locks and dams, ranking their relative severity (Fig. 1 and 2). The results show that many of the ice problems relate to specific project components. Their report included a qualitative discussion of operational, mechanical, heat, and manual solutions. Operational solutions included ice lockages, miter gate fanning, towboat assistance, and periodic cycling of dam gates. From a project component perspective, the most important ice control solutions were high-flow air bubblers used to retain and deflect brash ice, and emergency bulkheads or lift gates used to pass ice from the upper approach directly through lock chambers. Mentioned also were drift passes (openings in the river guardwall) to pass ice from the upper approach to nearby gates on the dam. Heat solutions included ice melting by steam, electric resistance heating, and hot water melting. Manual methods such as chipping ice with chisels and pushing ice with pike poles were still reported as widespread. Haynes et al. (1997) went on to describe many of these ice control methods in greater detail, focusing on recently developed electric heat applications developed by CRREL. The report also described the use of low-adhesion plastic panels to help ice shed from miter gate recess walls.

During the past two years, we visited a number of Corps lock and dam projects on the Ohio, upper Mississippi, and Illinois Rivers to determine what ice problems still persist and the impact of existing ice control solutions. The field visits also provided information on how well various types of lock and dam components perform in ice, the subject of this report. 


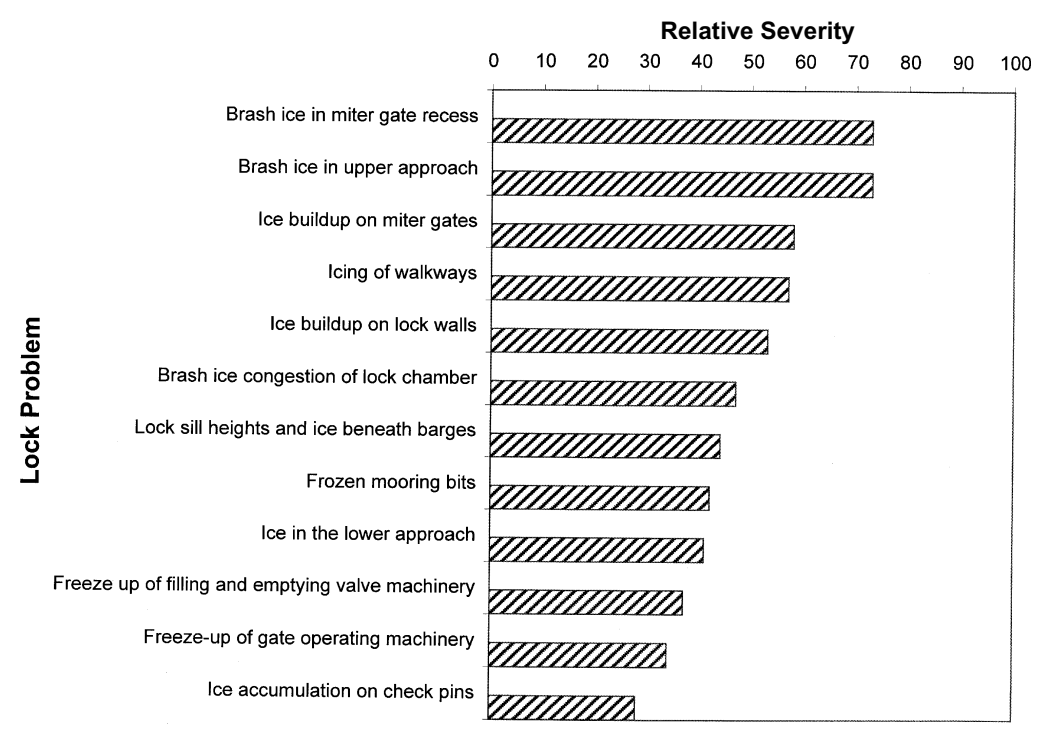

Figure 1. Relative severity of ice problems at Corps locks. (After Haynes et al. 1993.)

\section{ICE-AFFECTED COMPONENTS OF LOCKS}

Lock components and associated ice issues are listed in Table 1. The following section discusses how design aspects of these components affect their performance in ice.

\section{Upper lock approach}

Ice congestion of the upper lock approach is one of the most common winter operation problems at Corps locks and it leads directly to many other lock ice problems, such as brash ice in the gate recesses and lock chamber (Fig. 3). The layout and plan area of the upper lock approach and its configuration with respect to the upstream river channel greatly affects the volume of ice that collects upstream of locks. Heavy broken ice or frazil driven by the current or wind often collects in the upper approach, filling the area between the shore and the river guardwall. The problem is generally worse when the lock lies on the outside of a bend, as is the case for Montgomery Lock and Dam on the Ohio River, or when the prevailing winds are towards the upper lock approach, as at the Soo Locks. At Lock 19 on the Mississippi, ice congestion can be particularly severe due to hydropower intakes located along the upper approach.

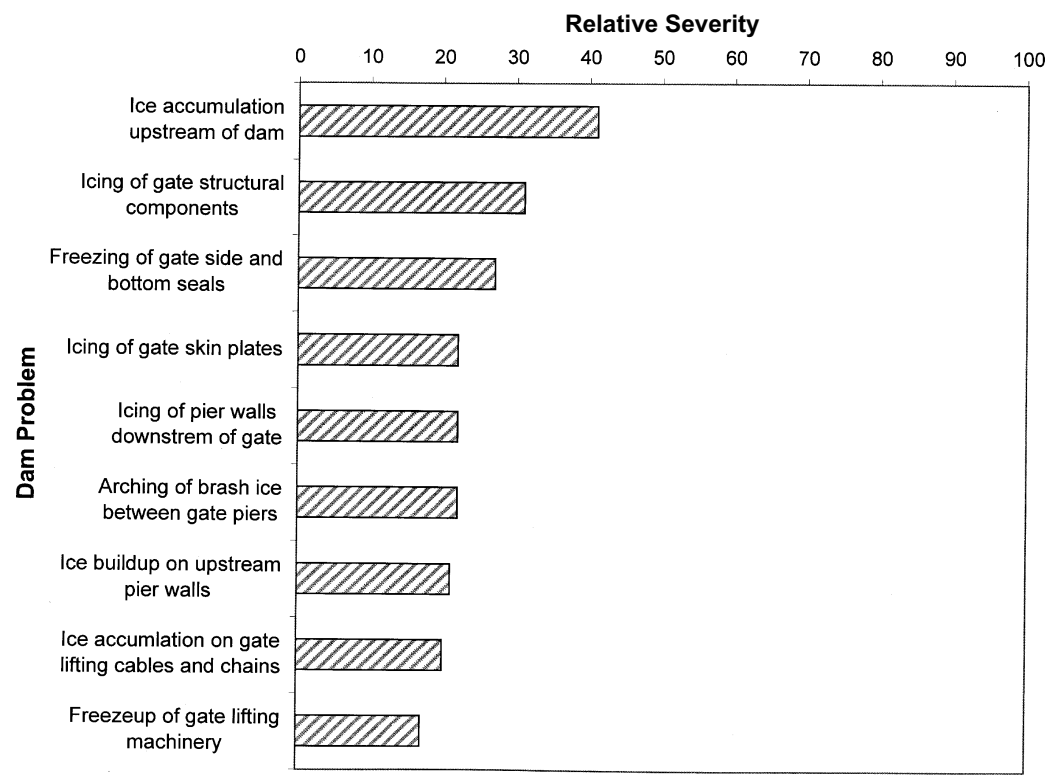

Figure 2. Relative severity of ice problems at Corps dams. (After Haynes et al. 1993.) 


\section{Table 1. Ice-affected lock components and related issues.}

Lock component

1. Upper lock approach

2. Miter gate recess

3. Lock walls

4. Miter gates

5. Submergible lift gates and emergency bulkheads

6. Lock sills

7. Guardwalls, guidewalls, and mooring cells

8. Culvert intakes, outlets

9. Filling and emptying valves

10. Filling port systems

11. Bubbler systems

High-flow sill curtains and recess flushers

Low-flow ice suppression bubblers

12. Ice melting systems

Thin panel electric heaters

Steam systems

13. Low-adhesion panels
Ice issue

Brash ice collects and enters lock with tows

Brash ice and ice collars prevent full miter gate opening

Icing and ice collar formation reduce usable width of lock chamber

Brash ice in gate recess and icing of gate trusswork

Allow ice skimming through lock chamber

Freezing of lifting chains and cables

Clearances with ice trapped beneath barges

Ice passage from upper approach to dam gates

Ice movement in approaches during lock filling and emptying

Ice clogging

Ice movement in lock chamber during lock filling and emptying

Reduce brash ice entering lock and clear brash ice from miter gate recess

Prevent ice formation in critical areas

Shed ice from gate recess walls

Melt ice from lock walls and machinery

Shed ice from gate recess walls

Enclose miter gate trusswork
Even in the absence of wind or water current, downbound tows continually rebreak the ice on the navigation channel and push it into the upper lock approach. If the upper lock approach is a canal, ice congestion can be particularly bad, examples being the Soo Locks, Lock 27 on the Mississippi, and Marseilles Lock on the Illinois Waterway.

The common, but time-consuming, solution is to lock the ice through, either with the tows, or as a separate ice lockage. Under severe conditions, as many as four ice lockages may be needed to pass a single tow, and delays can be as great as 24 hours.* Provided the up-

*Personal communication, John Anderson, Lockmaster, Montgomery Lock and Dam, Ohio River, October 1998.

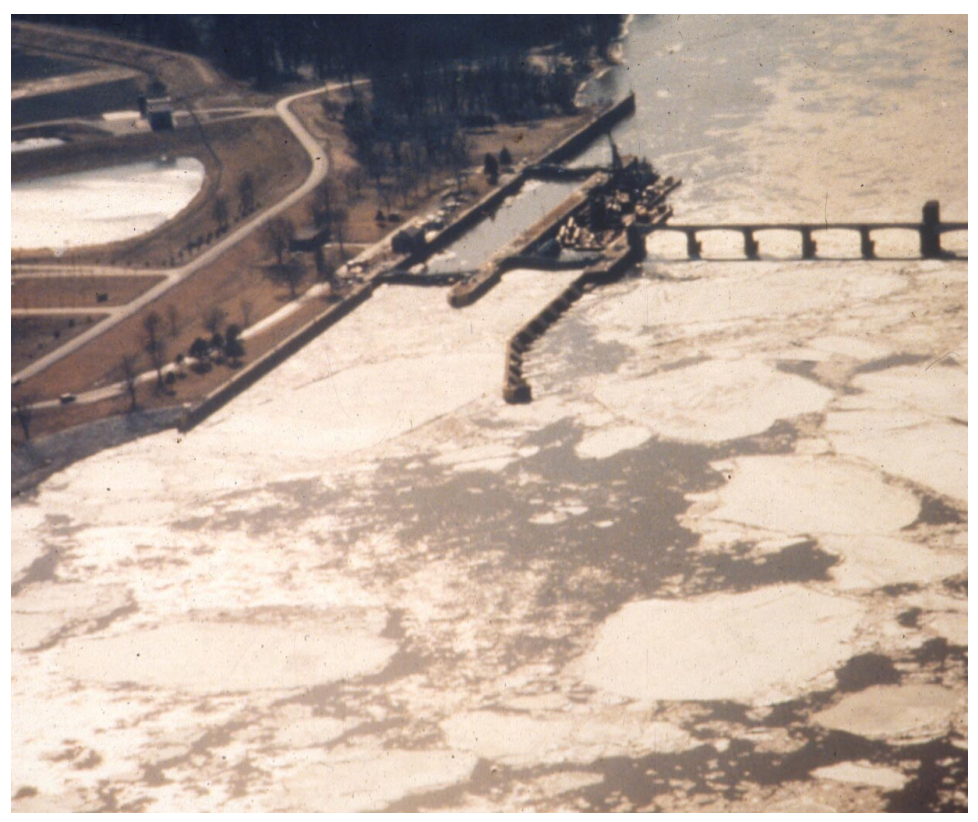

Figure 3. Ice accumulation in the upper approach at Lock and Dam 21 on the upper Mississippi River. 
stream ice accumulation is loose, opening the upper miter gates and the lock emptying valves creates sufficient water current to draw ice into the lock chamber. The ice is locked down and then flushed from the chamber with the lower miter gates open and the filling valves open. At some projects downbound barges are flushed out of the chamber by the same method. One requirement to ice locking is that the filling and emptying valves must be able to close under head, a feature of the widely used reverse-tainter valves, but not of the roller valves found on some of the Illinois Waterway Locks. If flushing with filling valves is not possible, free towboats are used to push or wash ice out of lock chambers.

If the ice accumulation is loose and there is sufficient river flow, upper approach ice may be diverted and drawn through adjacent dam gates, provided the ice can get around the end of the river guardwall. An upstream-blowing wind also helps. If the project has parallel locks, ice from the upper approach can be locked or skimmed through an auxiliary lock while the main lock handles vessel traffic. The emergency skimmer bulkheads or submergible lift gates required for this practice are described in "Submergible lift gates and emergency bulkheads."

The upper approaches to 1200 -ft locks are typically much larger than those of the older 600 -ft locks due to their longer river guardwalls. As a result, the ice collection area can be three to four times as large. Passing this additional ice or debris is an important consideration in the planning of new, larger locks or lock extensions.

In terms of passing ice, the new Mel Price Lock and Dam on the Mississippi at Alton, Illinois, completed in 1989 , is a success story. Here the upstream ice accumulation problem experienced at the old structure was greatly reduced by locating the new main lock chamber near the center of the river channel rather than along a bank (Fig. 4). In addition to the improved location of the lock, a submergible lift gate at its upstream end allows ice in the upper approach to pass continuously through the lock chamber without accumulating in either the upper or lower approach (Sorrell 2000). This concept is discussed in greater detail in "Submergible lift gates and emergency bulkheads."

\section{Miter gate recesses}

Brash in the miter gate recesses greatly hinders winter operation by preventing the miter gates from fully opening (Fig. 5). Once this situation begins to occur, the Corps may require the barge industry to limit the length and width of its tows, a measure that greatly reduces the cargo capacity of the waterway system. Locking tows in ice with partially opened miter gates is not

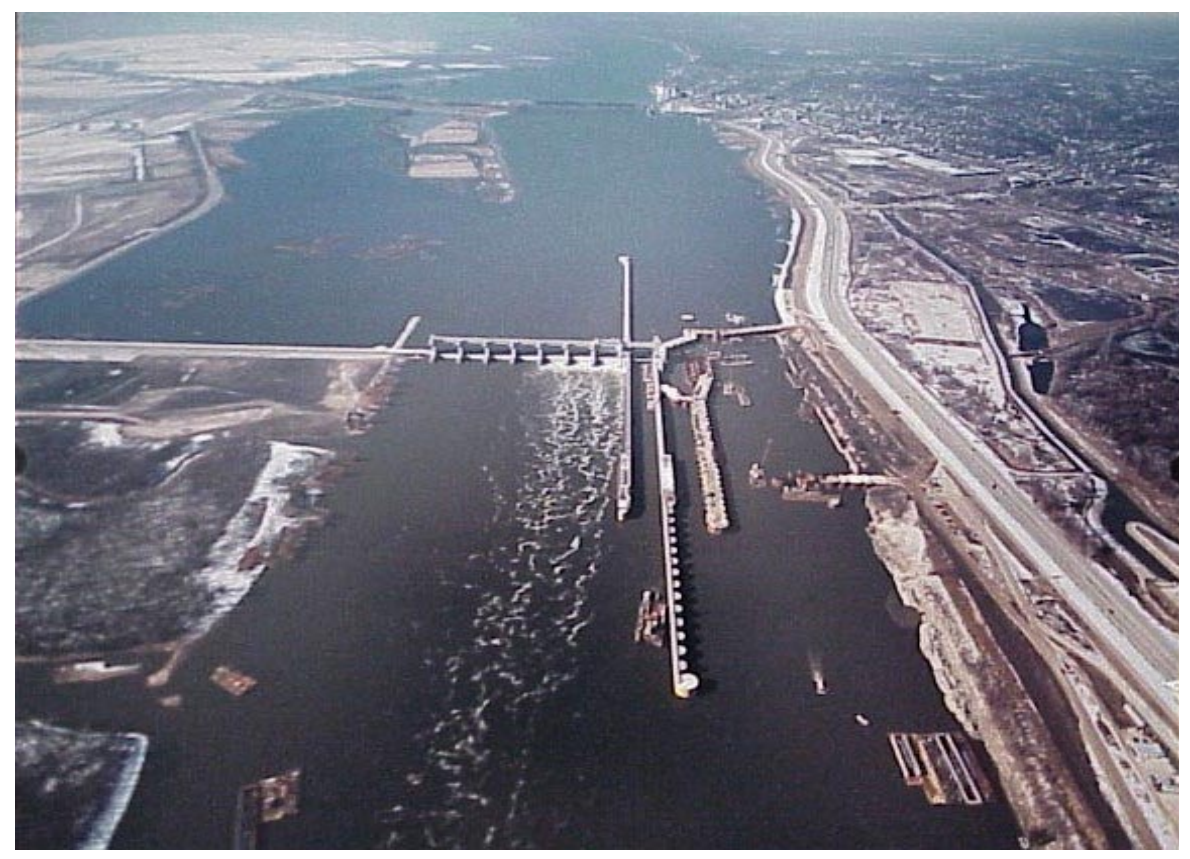

Figure 4. Mel Price Lock and Dam on the Mississippi River at Alton, Illinois. 


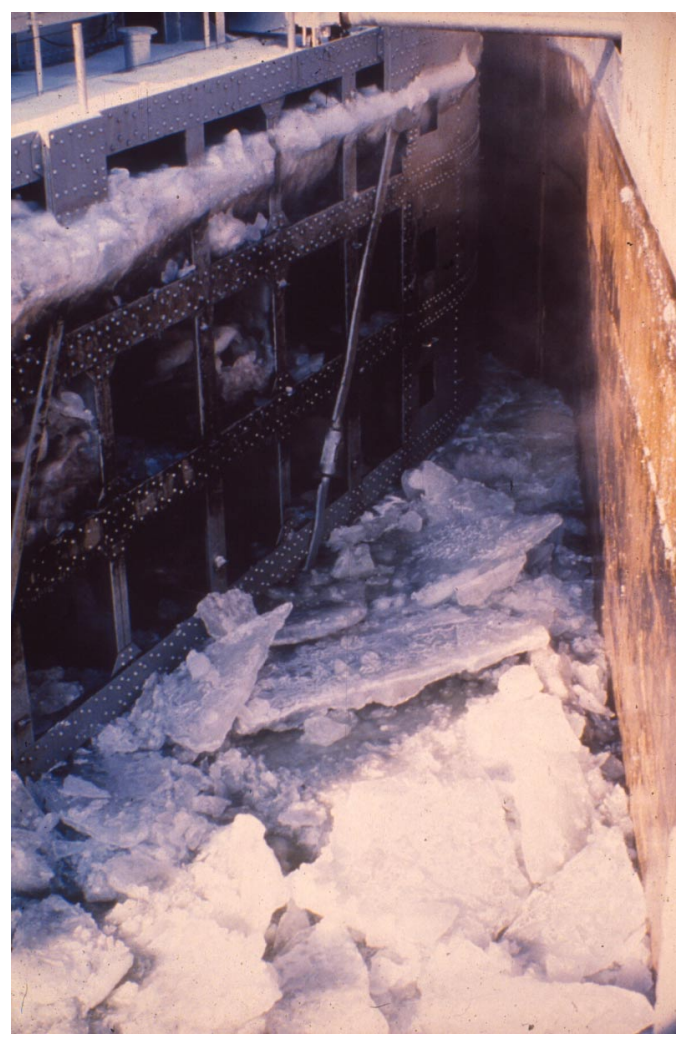

Figure 5. Brash ice in the miter gate recess.

an ideal solution as it exposes the gates to possible damage by barge or ice impacts.* During the past decade of relatively mild winters, width restrictions occurred on the Illinois Waterway on average for about one to two weeks. In the seventies and eighties, however, severe ice would commonly limit tow size for periods of more than a month. $\dagger$

Ice trapped between the back of the miter gate and the recess wall can damage the gate and over-stress the gate hinge mechanisms. Examples are dents in the steel skin plates on the backs of the miter gates at Starved Rock Lock on the Illinois Waterway and cracks in the welds on the old miter gates at Lock 20 on the upper Mississippi.§ In the past, operators were limited to manually clearing brash ice from the recesses using pike

\footnotetext{
*Personal communication, Larry Collins, Lockmaster, Starved Rock Lock and Dam, August 2000.

†Personal communication, Larry Collins, Lockmaster, Starved Rock Lock and Dam, and Jim Hart, Lockmaster, Marseilles Lock and Dam, August 2000.

§Personal communication, Bill Gretten, Operations, Rock Island District, January 1999.
}

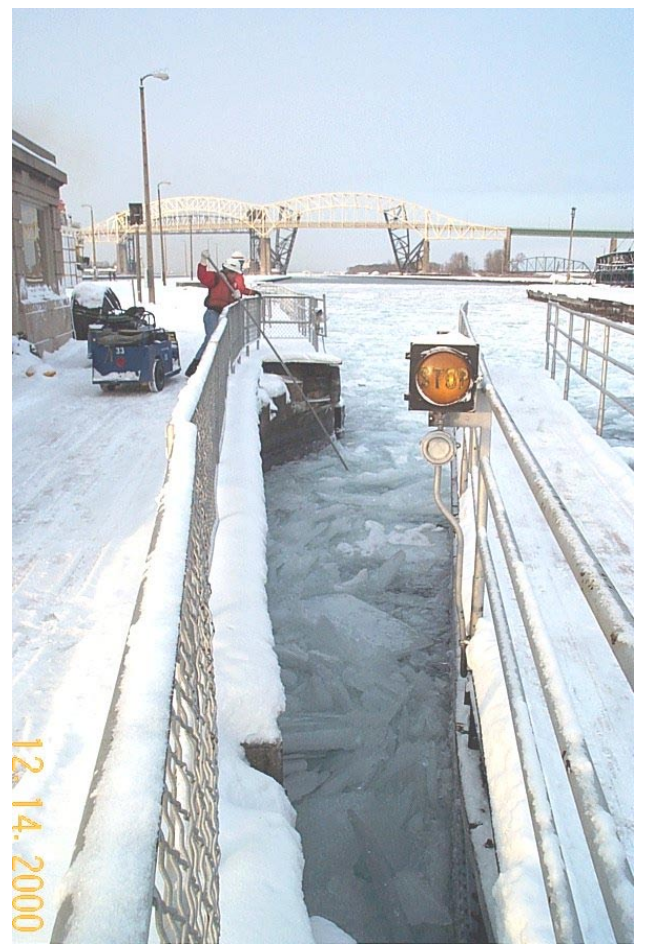

\section{Figure 6. Clearing brash ice from the gate recess with a pike pole at the Soo Locks.}

poles and ice rakes (Fig. 6). Another method at their disposal is to open the emptying valves with the chamber at high pool to draw the ice out of the miter gate recesses and into the chamber. Closing the emptying valves then creates a "backwash" effect and a temporary upstream current that also helps clear the ice from the recess area. Operators also swing the miter gates back and forth or "fan the gates" in an effort to force the ice out of the recess. Many believe that gate fanning causes premature wear and tear on gate support systems and operating machinery. High-flow air bubblers, termed "recess flushers," described in "Bubbler systems" have greatly alleviated the problem of brash ice in the gate recesses.

Problems of ice buildup on the walls of the miter gate recesses, known as "ice collars" or "ice ledges," still plague many locks (Fig. 7). As with brash ice congestion of the gate recess, the growth of ice collars prevents the miter gates from fully opening and leads to width restrictions. Solutions to the gate recess icing are more elusive than those to the brash ice problem. They include miter gate design, electric heaters, and low adhesion panels and are discussed in "Miter gates," "Electric heaters," and "Low-adhesion panels," respectively. 


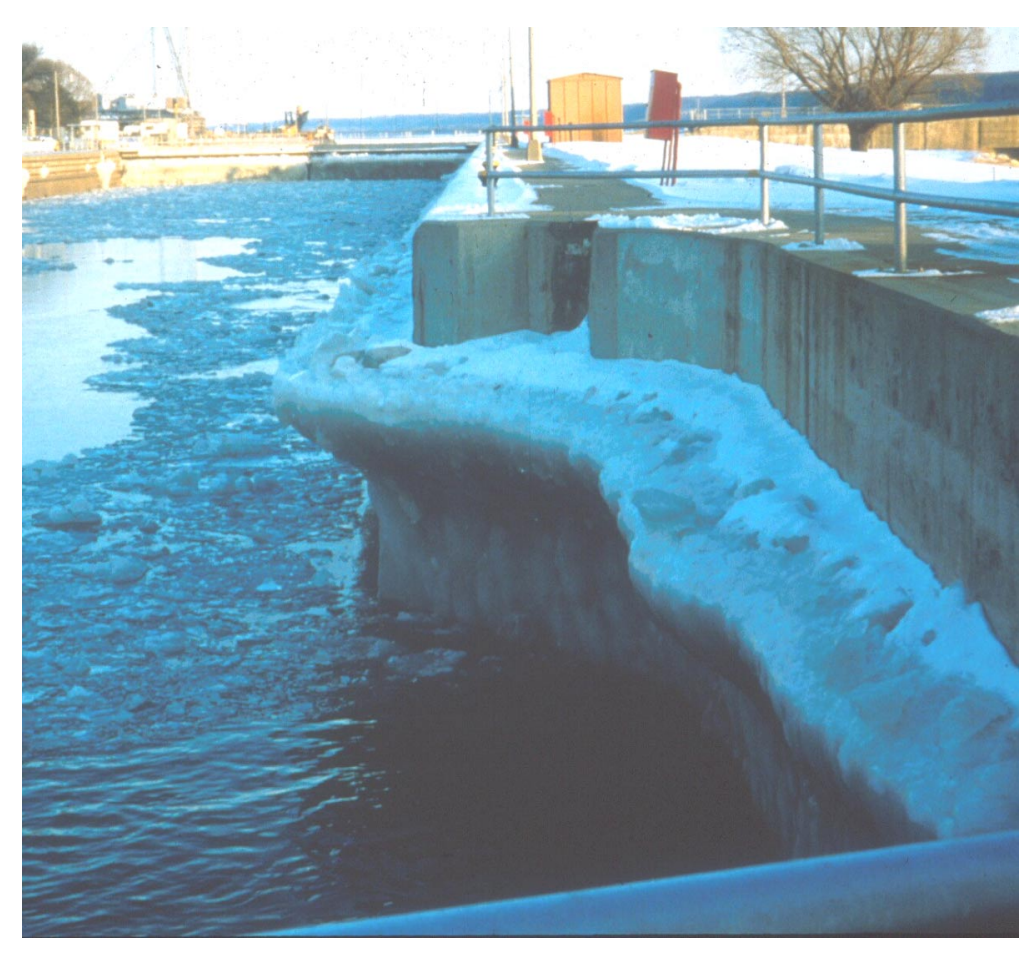

Figure 7. Ice collars in the gate recess and on the lock wall.

\section{Lock walls}

Lock walls, like the gate recesses, are extremely susceptible to icing and the formation of ice collars. With repeated wetting from the lowering and raising of the chamber, the ice adheres extremely well to the worn concrete and steel rub plates typical of many Corps locks. The thickest buildups typically form at the high pool level and can achieve widths of greater than $3 \mathrm{ft}$, preventing 105 -ft-wide tows or vessels from entering 110 -ft-wide locks (Fig. 7). Typically, lock wall icing is more severe on north-facing than south-facing walls due to the beneficial effect of solar radiation. Some believe that ice collar formation can be reduced by keeping the chamber at high pool when not in use.* A possible explanation is that, at high pool, most of the wall area is submerged and therefore protected from subfreezing air temperature.

The most common method for removing ice from the lock walls is still chipping, which is an extremely slow and labor-intensive process. If a portable steam generator is available, steaming is more effective but still time-consuming. Some Corps facilities rent

*Personal communication, Guenther Frankenstein, Chief (Retired), Ice Engineering Research Branch, U.S. Army Cold Regions Research and Engineering Laboratory, Hanover, New Hampshire, October 2000.
"Hotsy" brand, high-pressure hot-water washers, which have the advantages of being portable and readily available, but are slow, especially if a large area is to be deiced.

The most effective solution for deicing large areas was the copolymer coating tested at the Soo locks in 1979, during the Winter Navigation Program (Frankenstein and Hanamoto 1983) (Fig. 8). The coating was relatively costly to apply, though, requiring steam cleaning of the lock wall and an epoxy undercoat. To remove the ice, some steaming was required, but the ice came off the coated lockwall much more easily than from untreated concrete. Within a few years, vessels had scraped off most of the coating, and it was not reapplied because of cost and the fact that winter-long operation of the Soo Locks has been discontinued.

\section{Miter gates}

Brash and slush ice packed into the trusswork of miter gates by vessels increases the total weight of the gate leaf, stressing supports and gate operating equipment (Fig. 9). These ice accretions also impinge against the recess wall, preventing full gate opening. The severity of this problem depends somewhat on miter gate design, important factors being the clearance between the back of the recessed gate and the wall of the recess, and the location of the gate skinplate with respect to the trusswork. 


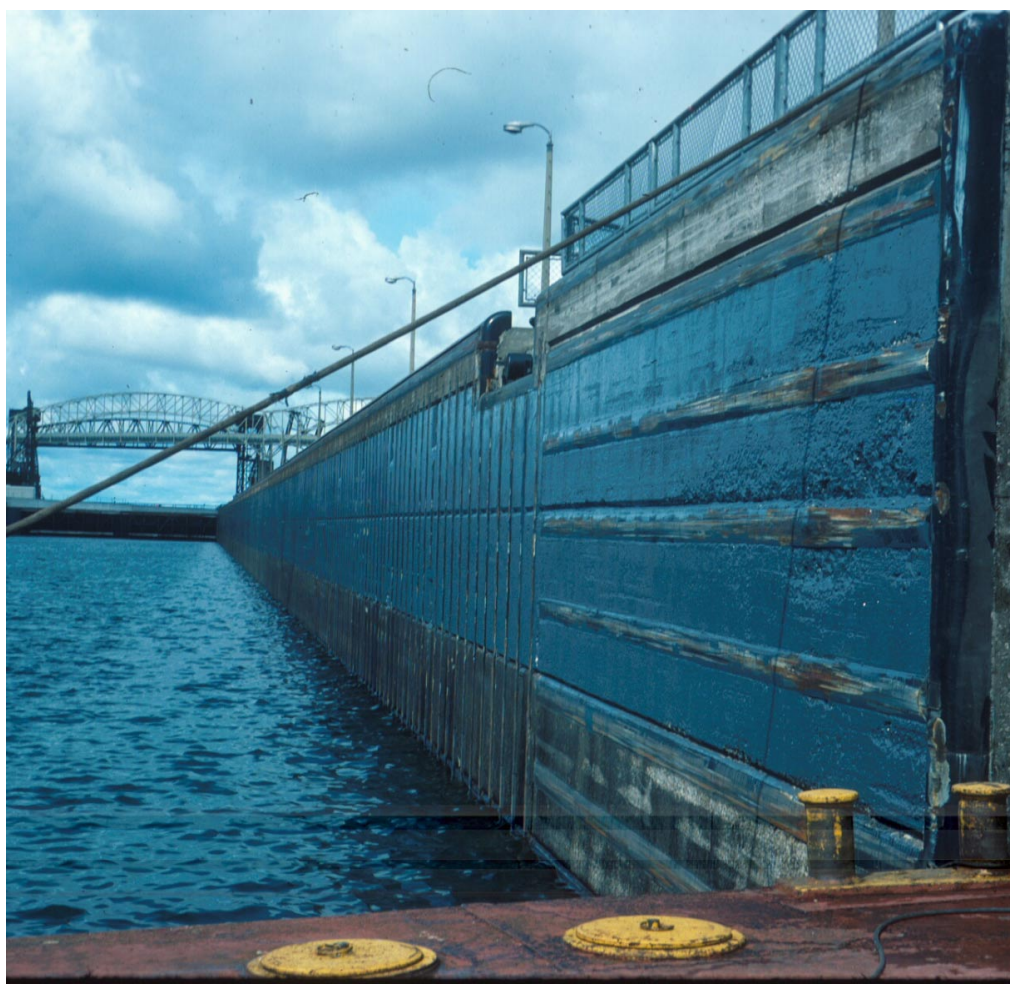

Figure 8. Copolymer coating at the Soo Locks.

On the older miter gates on the Illinois Waterway, the skinplate is continuous along the downstream side, wrapping around the upstream side for distances of about $8 \mathrm{ft}$ at the quoin and the miter (Fig. 5). When the gate is open, the distance between the back of the gate and the recess wall is only about four inches, leaving very little clearance for brash ice or ice collars on the recess wall. Under heavy brash ice conditions,

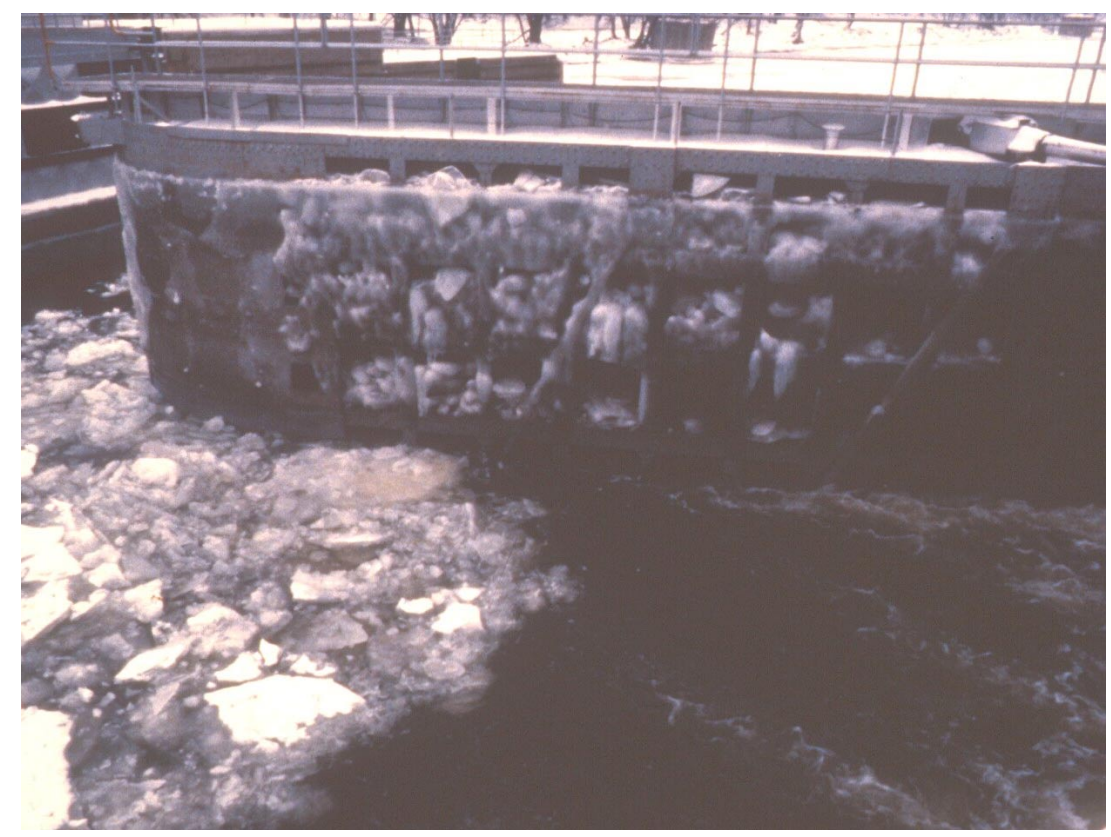

Figure 9. Icing of the miter gate trusswork. 


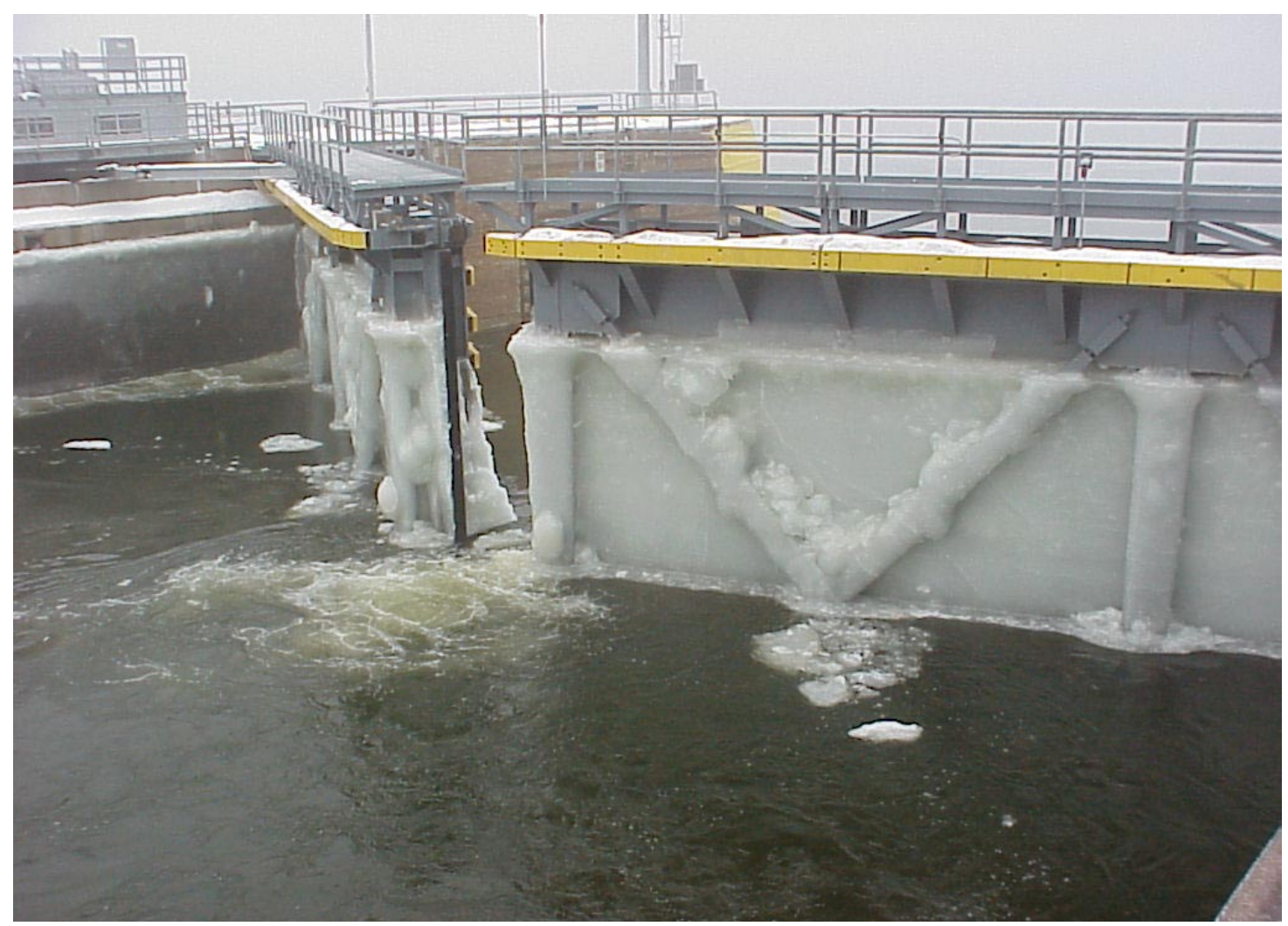

Figure 10. Miter at Lock 24 on the upper Mississippi with widely spaced structural members on the upstream side.

downbound tows would push ice into the lock and pack it into the trusswork on the upstream side of the lower gates. Protruding ice would have to be removed with great difficulty before the gates could be fully recessed. Replacement miter gates with the steel skinplate on the upstream rather than the downstream side have solved this problem at Marseilles and Dresden Island Locks, on the Illinois Waterway. In addition to eliminating the trusswork icing problem, the gate is thinner, providing about 12 inches of clearance between the skinplate and the recess wall.

Miter gates on the upper Mississippi are designed with the skinplate sandwiched between the structural members. The structural components on the upstream side of the gates are larger and more widely spaced than those of the older Illinois River miter gates and less prone to trapping brash ice (Fig. 10).

At many upper Mississippi locks, low-flow air diffusers along the bases of the gates help circulate warmer water from below to suppress surface ice formation on the upstream sides of the gates ("Bubbler systems").

At the Soo Locks, plywood panels enclose the trusswork on the downstream side of the miter gates, and steam diffusers inside the gate provide heat to melt ice off the gate exterior. Ultra-high molecular weight (UHMW) polyethylene panels will soon replace the plywood because of their improved durability and lower coefficient of friction. During the three-month winter closure of the Soo Locks, thermally grown ice many feet thick can form on the upstream sides of the gates, particularly when the lock is de-watered. Before the enclosures and the heat were used, removing these thick ice deposits was a problem when the lock reopened in the early spring of each year.

\section{Submergible lift gates and emergency bulkheads}

If an adjacent lock is equipped with submergible lift gates or special overflow bulkheads at its upstream end, ice may be skimmed through the lock chamber (Fig. 11). Ice and debris passage is a side benefit of this equipment whose main purpose is emergency lock closure to maintain pool in the event of miter gate failure. This practice is very effective at many of the newer projects on the Ohio River and at the new Mel Price Lock, opened in 1989 on the Mississippi River.

The common practice on much of the Ohio is to skim ice through the auxiliary lock chamber while passing 


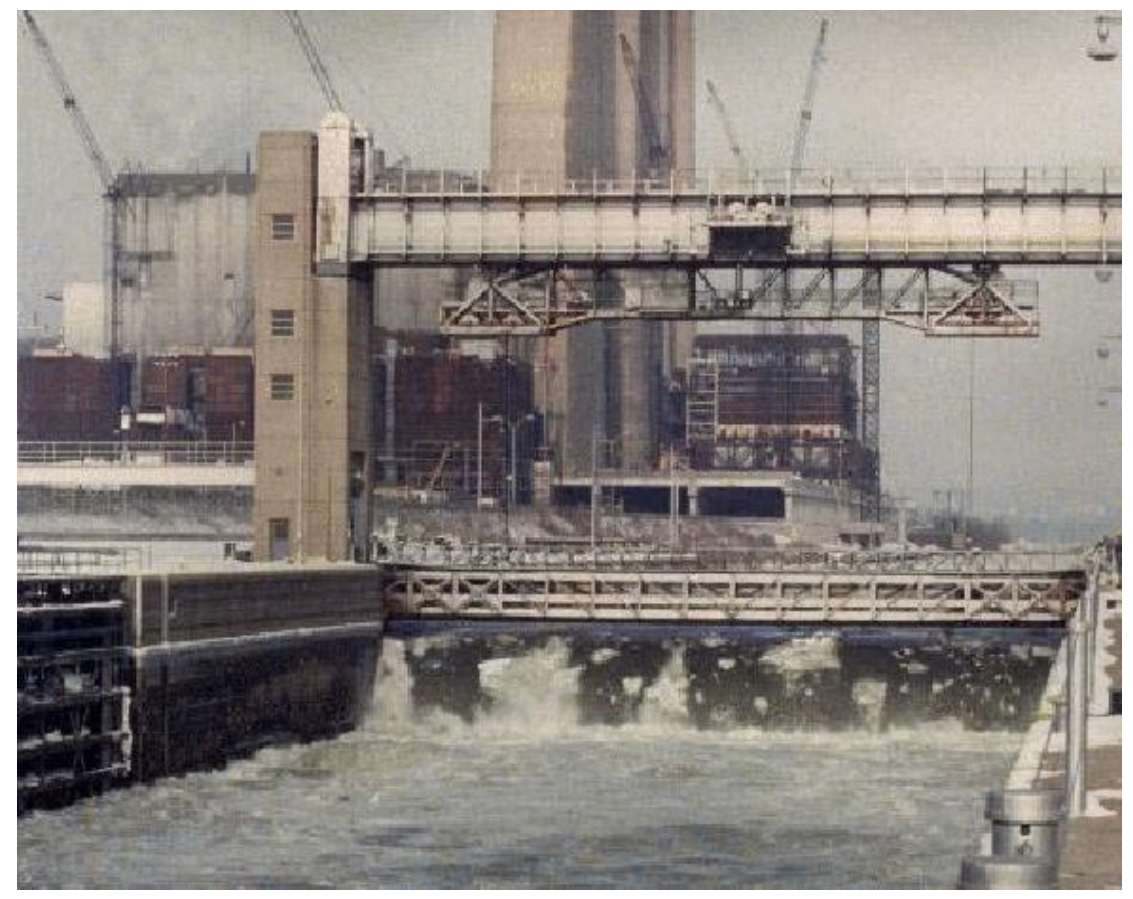

\section{Figure 11. Skimming ice over emergency bulkheads at New Cumberland Lock on the Ohio River.}

barge traffic through the main chamber. Pittsburgh District's New Cumberland, Pike Island, and Hannibal Locks and Dams place 110-ft-wide by 9-ft-high emergency bulkheads to pass ice using the service bridge crane. The second from the top, a "skimmer bulkhead" designed for overflow, sits 3 to $5 \mathrm{ft}$ below upper pool level. The miter gates are latched in their recesses and the top bulkhead is hoisted out of the water surface to skim ice. The top bulkhead is replaced to interrupt the flow and avoid adverse outdraft effects on passing tows. Several projects have experienced freezing of the bulkhead latching mechanisms, but, for the most part, application of heat trace has solved this.* Huntington District Projects-Willow Island, Belleville, Racine, R.C. Byrd Greenup, and Meldahl — use submergiblelift emergency gates to skim ice in the same manner as the upstream projects use their emergency bulkheads. Many of the lockmasters interviewed on the upper Ohio believe that their submergible gates and skimmer bulkheads are the most valuable ice management tool at their disposal. $\dagger$ In spite of their usefulness in ice and

*Personal communication, George Stephens, Lockmaster, New Cumberland Lock and Dam, October 1998.

$\dagger$ Personal communication, George Stephens, Lockmaster, New Cumberland Lock and Dam, and Larry Circle, Lockmaster, Racine Lock and Dam, October 1998. debris control, districts are seriously considering eliminating emergency gates from planned new locks and rehabs because of their expense.

Upper Mississippi River Locks 19, 26 (Mel Price), and 27 have submergible lift gates at the upstream ends of their main chambers. Although ice congestion in the upper approach at Lock 19 can be extreme, the lift gate is not submerged to pass ice because of ice clogging problems with the hoisting cable recesses and difficulties in flushing the ice out of the confined lower approach. As mentioned in "Upper lock approach," passing ice over the upper gate of the main lock and through the chamber is extremely successful at Mel Price (Fig. 12). To augment the current in the chamber, the filling valves are left partially open during the flushing operation. As Lockmaster Tom Miller explains, "Lift gates are more temperamental than a miter gate and they require more maintenance, but they really make up for it during the winter months." (Sorrell 2000)

Skimming ice, though effective, carries potential hazards. For example, during the winter of 2001, while running ice through the main lock chamber at Mel Price, one of the downstream miter gates was caught by the current and swept past the miter gate sill. Until then, operators had relied on the hydraulic pistons, rather than latching mechanisms, to hold the gates open while flushing ice. The repairs took four months, forcing one of the busiest navigation projects in the nation to rely on a 


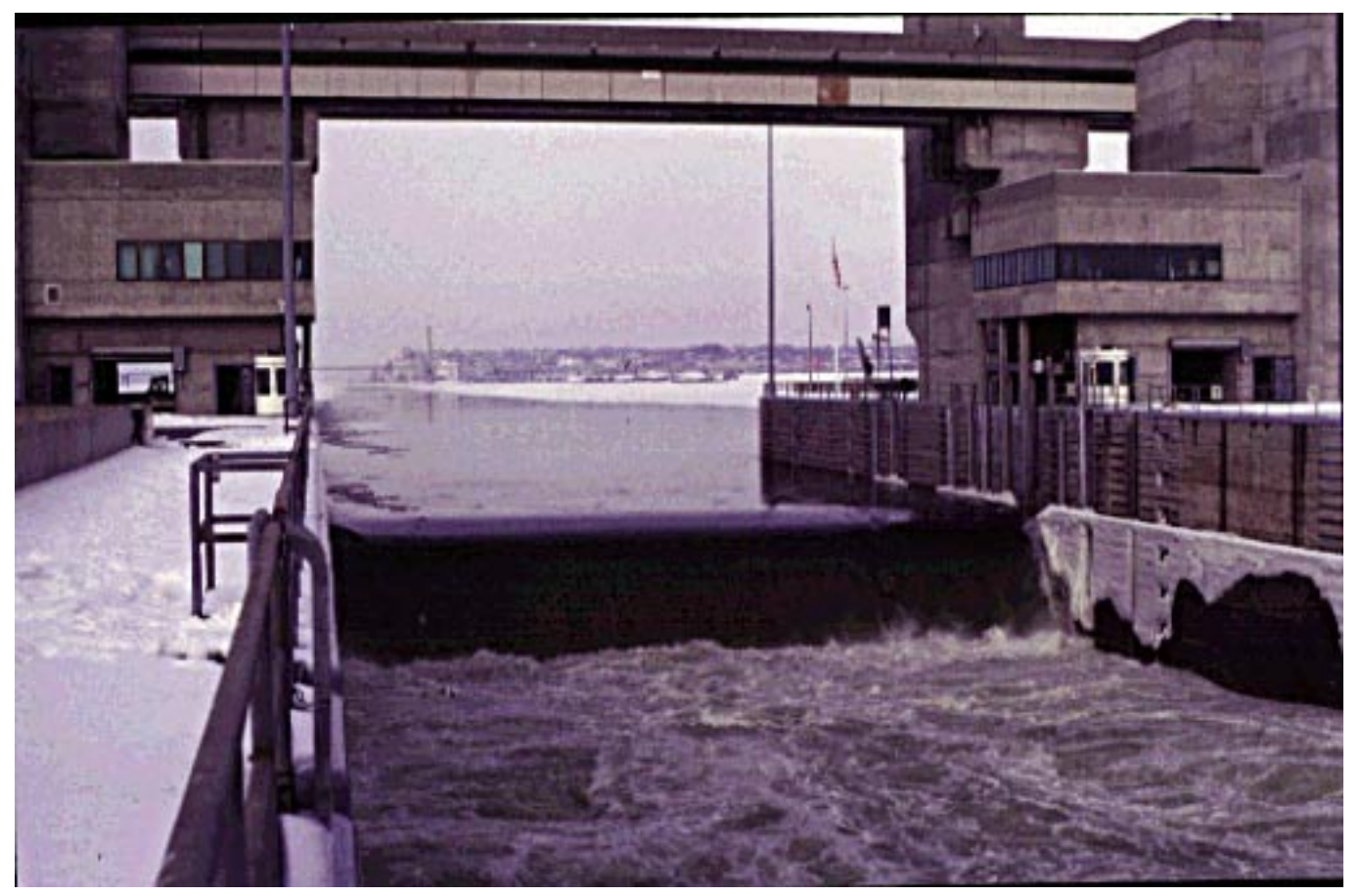

Figure 12. Submergible lift gate at Mel Price Lock.

single 110 -ft by $600-\mathrm{ft}$ lock chamber. A possible explanation is that ice in the miter gate recess prevented the gate's full opening, causing it to protrude into the flow.

\section{Lock sill heights and brash ice beneath barges}

Brash ice beneath barges presents a serious problem during winter lockages. This ice accumulates as the tows negotiate the ice-filled reaches and makes it difficult for the tow to enter the lock. Tows moving through icecongested channels accumulate considerable ice beneath their bottoms. By some estimates, this ice can be as thick as $8 \mathrm{ft}$ and damage to the sill can result as the tow passes over.* Brash ice beneath barges may also pack into the filling intakes if they are located beneath the gate sill ("Culvert intakes and outlets"). Davis (1989) recommends that the minimum sill depth should be twice the design draft of the vessels using the lock. By this criterion, minimum depth over the sill for a tow drafting $9 \mathrm{ft}$ would be $18 \mathrm{ft}$, but at most projects the clearance is less.

When locking down, barges with ice beneath may come to rest directly on the lock floor, and, because there is usually more ice beneath the center barges, the barges settle unevenly, snapping the connecting cables

*Personal communication, Chris Morgan, Lockmaster, Lock 24, Mississippi River, August 2000. and jeopardizing crew safety. Structural damage is also possible to the lock floor and the filling port system ("Ice congestion of lock chambers"). When a tow bottoms out because of ice, lock operators respond by refilling the lock in an effort to redistribute the ice more evenly. Projects reporting ice impacts to sills, and barges grounding in the lock chamber because of ice, include Locks and Dams 20, 24, and 25 on the upper Mississippi.*

\section{Guidewalls, guardwalls, and mooring cells}

Where long river guardwalls separate the upper lock approach from the dam section, the potential for clearing ice and debris from the upper approach through adjacent dam gates is limited. If air temperature is above freezing and if ice accumulation is loose and winds are favorable, in some instances it may be possible to draw ice out of the upper approach and pass it through adjacent dam gates. To do this, the ice must move either around the upstream end of the river guardwall or through openings in the wall or "drift passes." Most existing drift passes are too narrow to be effective,

\footnotetext{
*Personal communication, Larry Reever, Lockmaster, Lock 20, Mississippi River; Chris Morgan, Lockmaster, Lock 24, Mississippi River; and Jerry Stroud, Lockmaster, Lock 25, Mississippi River, August 2000.
} 
though, a problem that is being corrected at Locks and Dams 24 and 25 on the upper Mississippi. At these sites, the original 15 -ft-wide drift passes are being widened to $30 \mathrm{ft}$ (Fig. 13).

Ice passage from the upper approach to dam gates is more feasible on the Illinois Waterway where, instead of a continuous river guardwall, isolated mooring cells prevent tows from drifting towards the dam. Depending on the plan configuration of the cells, it may be possible to pass ice from the upper approach between the cells to adjacent gates. This is the case at Peoria and Le Grange Locks, which are equipped with submergible tainter gates adjacent to the locks that regulate pool height and clear ice from the upper approach (Fig. 14).

\section{Culvert intakes and outlets}

Design and location of culvert intakes and outlets are important in terms of ice management at locks. During lock filling, water currents toward the intakes tend to accumulate ice and debris, which can interfere with the operation of the upper gates. Generally speaking, the closer the intakes are to the gates, the worse the problem. The problem can be particularly severe at Locks 18, 19, 20, and 21 on the upper Mississippi, when heavy frazil drawn into the culvert intakes can clog the filling valves and valve pits. Culvert intakes located in the approach walls upstream of the gate recesses, al- though more costly to construct, are favorable to intakes through the upper gate sill from an ice control standpoint. It is also much easier to clear debris from intakes located along the wall than from intakes located in the sill because the wall provides a better working platform for machinery. An example of a through-thesill intake is Lock 19 on the upper Mississippi. This design has been an ongoing maintenance headache for the Rock Island District.* Whenever possible, locating the intakes on the river side of the river wall is an ideal design solution in terms of reducing adverse currents and waves in the upper approach as well as minimizing ice and debris congestion in front of the upper gates.

Culvert outlet manifolds immediately downstream of the lower miter gates are ideal for flushing ice and debris out of the lower approach. A drawback is adverse outdraft on waiting vessels.

\section{Filling and emptying valves}

In some cases, frazil or brash ice drawn into the culvert intakes can clog the lock filling valves and put the lock out of service. This problem is particularly severe at Lock 19 on the Mississippi where the intakes are located in the upper gate sill, but it also occurs at locks

*Personal communication, Kenn Shoemaker, Assistant Chief of Operations, Rock Island District, December 2000.

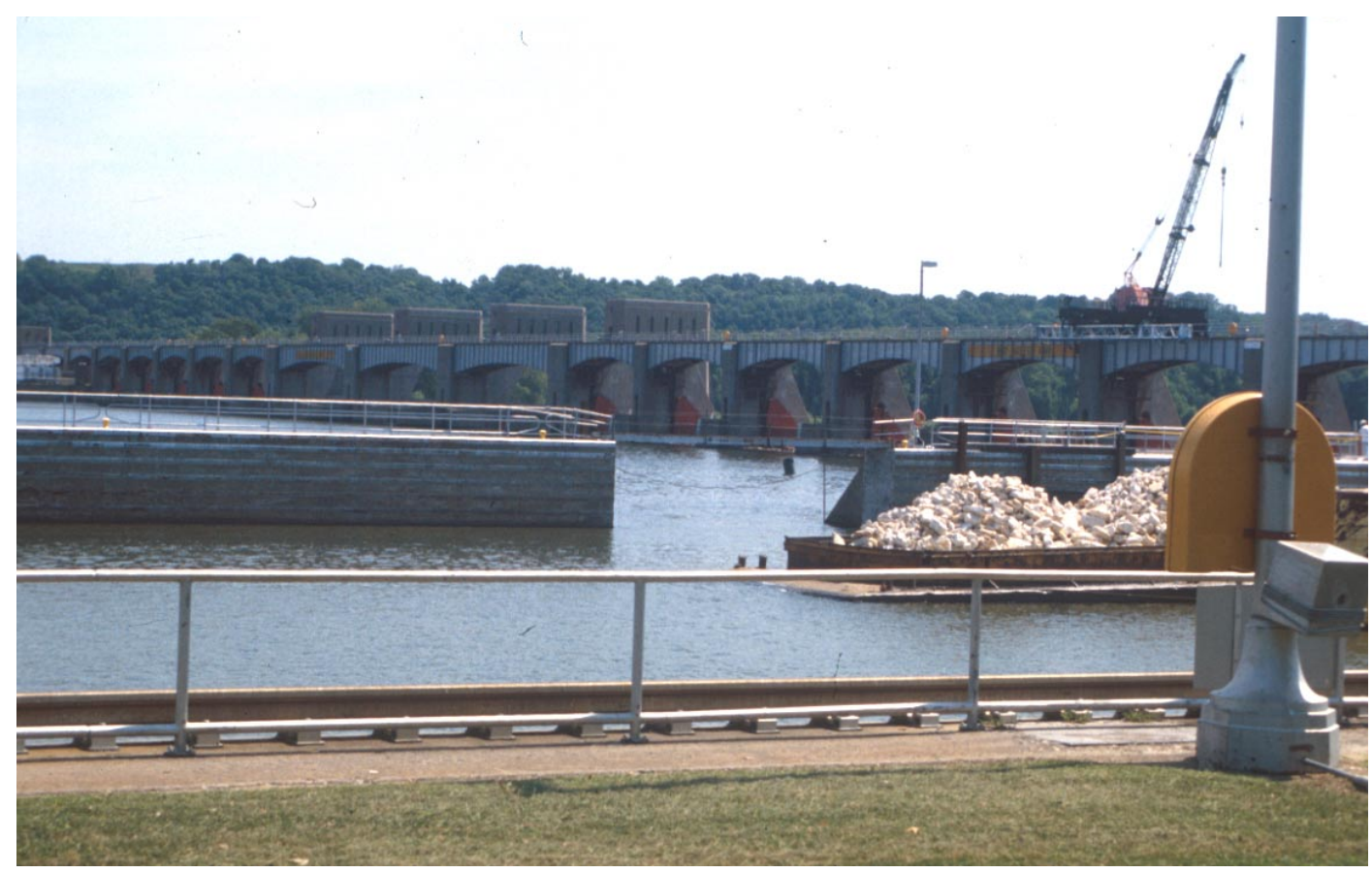

Figure 13. Drift pass in the river guardwall being widened at Lock and Dam 25 on the upper Mississippi. 


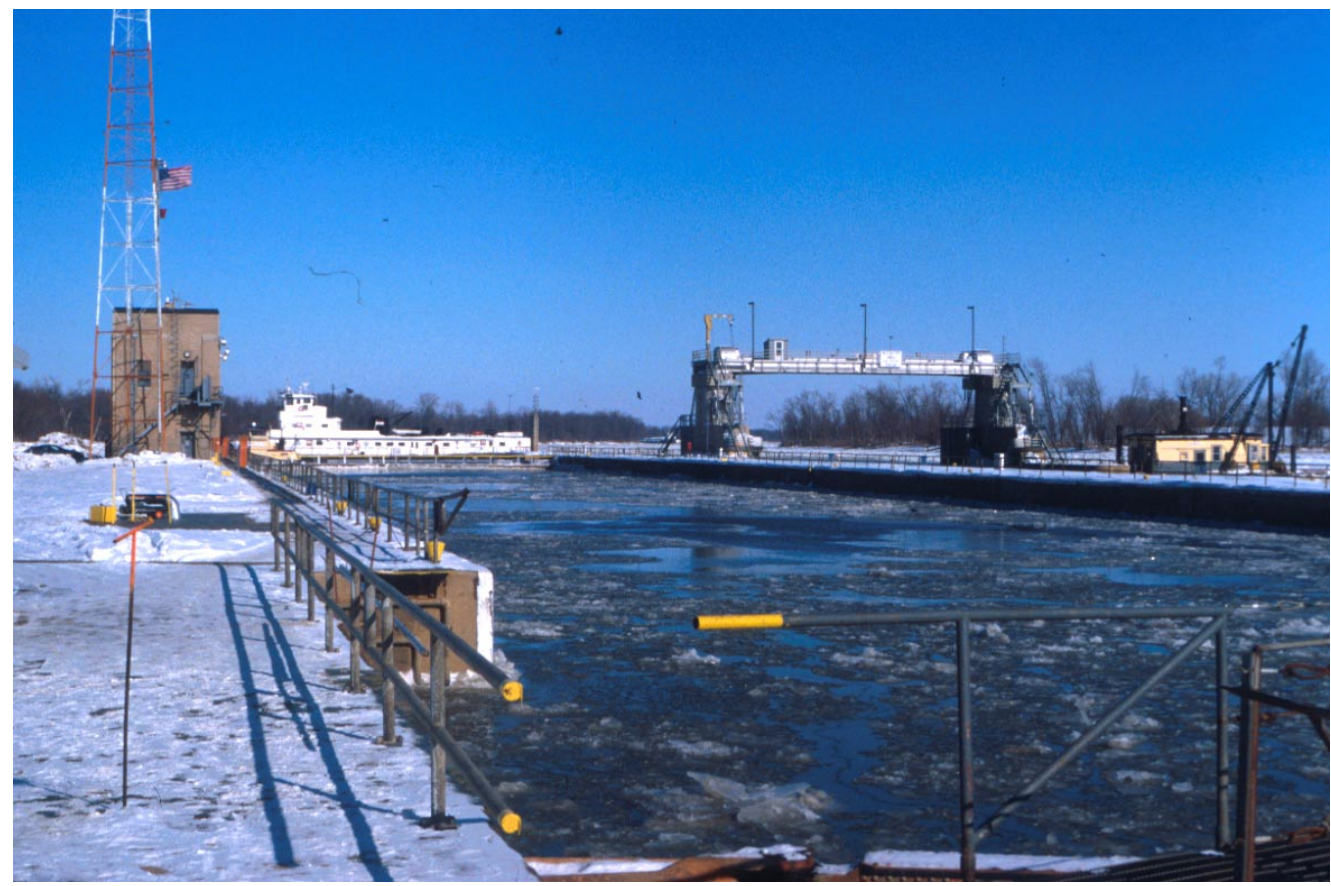

Figure 14. Le Grange Lock and Dam on the Illinois River. A free towboat washes brash ice from the upper approach, towards the submergible gate, adjacent to the lock chamber.

where the intakes are located along the walls of the upper approach, such as Mississippi River Locks 18, 20, and 21. At Lock 19 ice is removed from the filling valve pits using a dragline and bucket. Operators are sometimes able to clear the ice out of the culverts and valves by sequentially cycling the filling and emptying valves.* At Lock 18, letting the lock sit idle for 8-12 hours usually allows the frazil to melt. $\dagger$ The intake and valve-clogging problem can be avoided by slow-filling the lock with the filling valves only one-third to three-quarters open.

At projects that must lock ice, reverse tainter valves that can operate against a head are preferable to valves that cannot do so, such as roller valves, for the reasons described in "Upper lock approach."

\section{Ice congestion of lock chambers}

Brash ice congestion in the lock chamber is the direct result of ice in the upper approach that moves into the chamber with downbound vessel traffic. The common solution is to lock this ice through, at the expense

*Personal communication, William Robinson, Lockmaster, Lock 19, Mississippi River, August 2000.

$\uparrow$ Personal communication, Michael Robbins, Lockmaster, Lock 18, Mississippi River, August 2000. of delaying navigation ("Upper lock approach"). In some cases, sufficient ice is pushed into the chamber to cause tows to ground on the lock floor when the water level in the chamber is lowered ("Lock sill heights and brash ice beneath barges").

One problem common to ice lockages is the difficulty of flushing ice from the upper portion of the lock chamber when the chamber is at low pool. This is because the filling and emptying ports that create the iceflushing currents are typically located in the central portion of the chamber. A common solution on the Ohio River is to have a tow push the ice several hundred feet into the chamber, then back the tow out and tie it up to the wall as the ice is locked through.

At the Soo Locks, four 60 -cm-diameter manifolds, installed in the upper miter gates at the low-pool water level, create horizontal surface jets to move the ice out of the upper portion of the chamber (Fig. 15). Flow from the filling ports then creates sufficient downstream surface currents to flush the ice out of the middle-tolower portion of the chamber.

\section{Bubbler systems}

\section{High-flow air systems}

The development of high-flow bubbler systems during the last two decades has done much to solve brash 


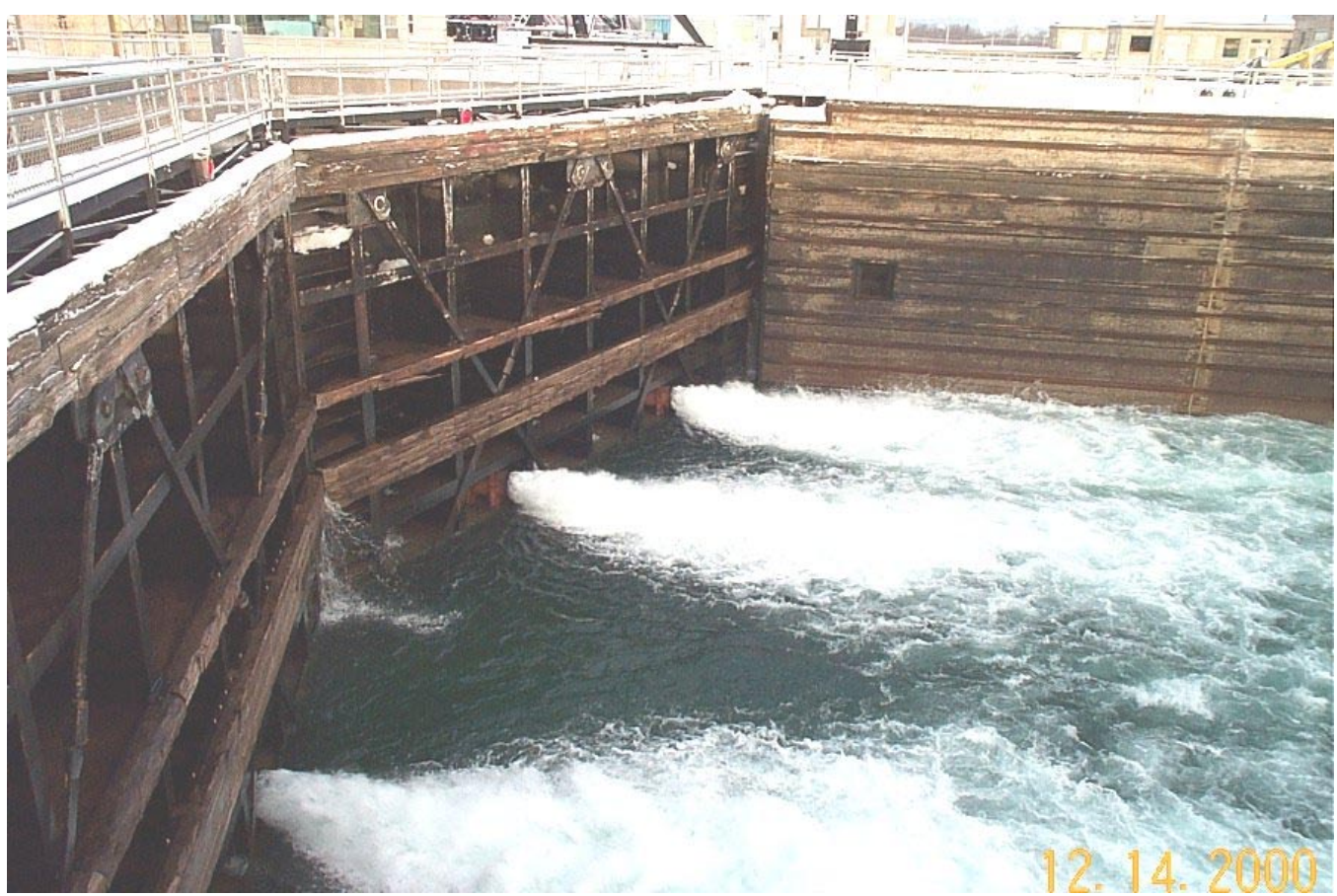

Figure 15. Ice flushing manifolds at the Poe Lock, Sault Ste. Marie, Michigan.

ice problems at Corps locks. This relatively low-cost solution is now widely accepted within the Corps, and high-flow systems are now installed during most major lock rehabilitation projects on ice-affected rivers. The typical system, developed by Hanamoto (1981) and Rand (1988) and refined at the districts, consists of air curtains in the four gate recesses and two lateral air curtains upstream of the miter gates (Fig. 16). Electric or diesel-powered compressors in the 5 - to $40-\mathrm{m}^{3} / \mathrm{min}$ range supply the diffusers via valve manifolds that permit the entire airflow to be switched to one diffuser at a time. Even with these high-flow air systems, some gate fanning is usually needed to move brash ice out of the gate recesses (Fig. 17).

High-flow air curtains across the upper gate sill, or aligned diagonally, help deflect the ice pushed ahead of barges, reducing the amount of ice that enters the lock (Fig. 18). Ice deflection is most effective when the deflected ice is continuously passed through an adjacent dam gate or a parallel lock chamber. A prototype 200 -ft-long diagonal diffuser, supplied by a $28-\mathrm{m}^{3} / \mathrm{min}$ compressor, was very successful at Peoria Lock for several winters in the late 1980s. The diffuser pipe, which was fastened to a series of weights resting on the muddy riverbed, was removed and never replaced when riprap bed protection was installed in the upper approach.

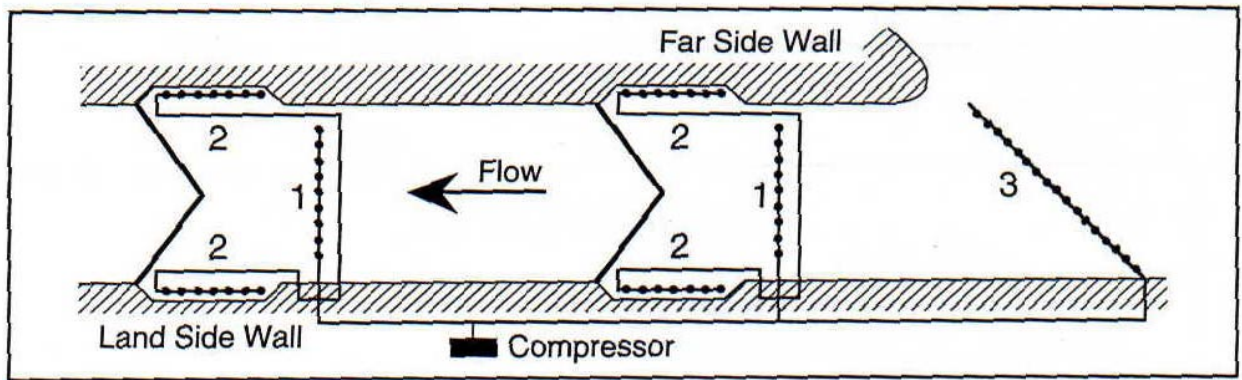

Figure 16. Plan view of a high-flow bubbler system. Numbers indicate various component types: (1) sill curtains, (2) gate recess flushers, and (3) deflector air curtain. (From Haynes et al. 1997.) 


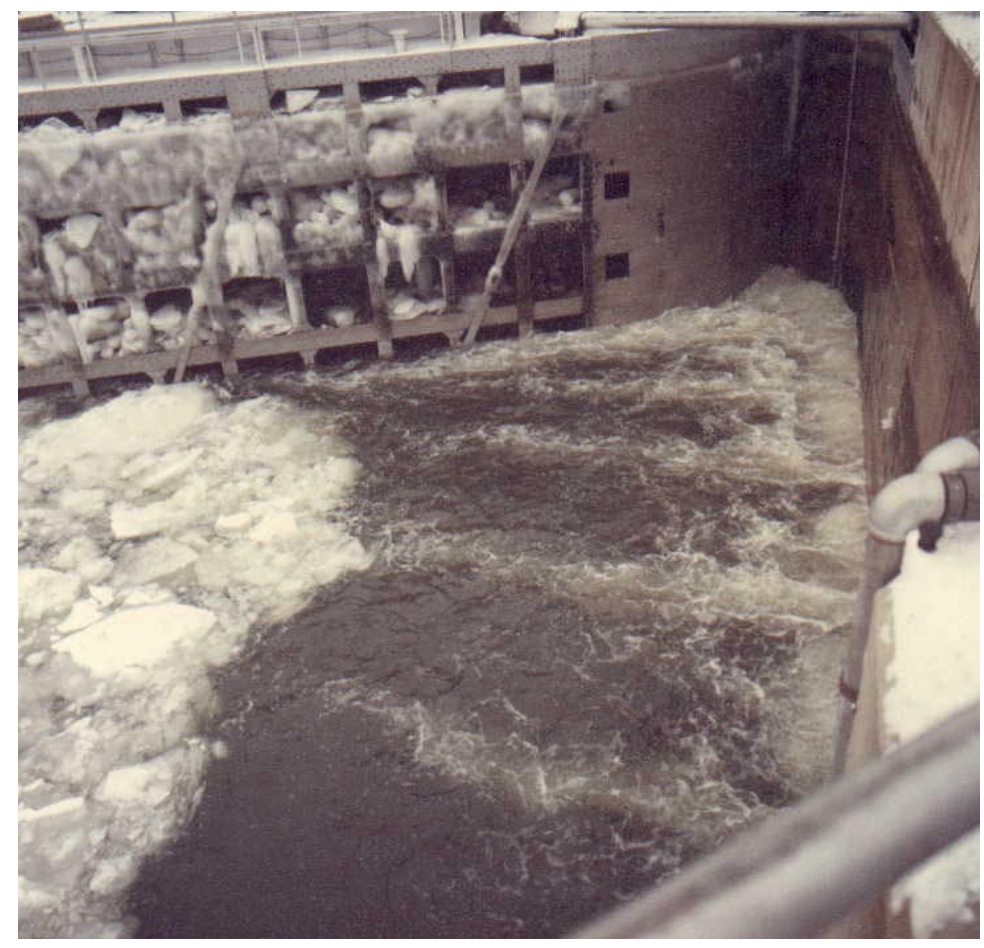

Figure 17. Gate recess flusher at Starved Rock Lock.

\section{Low-flow ice suppression bubblers}

Many locks on the upper Mississippi use low-flow air systems to suppress ice growth in the quoin areas on the upstream side of their miter gates. Once the ice season starts, 5-HP vane blowers continuously supply air to one-inch diffuser lines along the bases of the gates to bring up warmer water from the bottom ("Miter gates"). Although the blowers present maintenance problems and must be rebuilt on a regular basis, lock operators believe they are beneficial and continue to

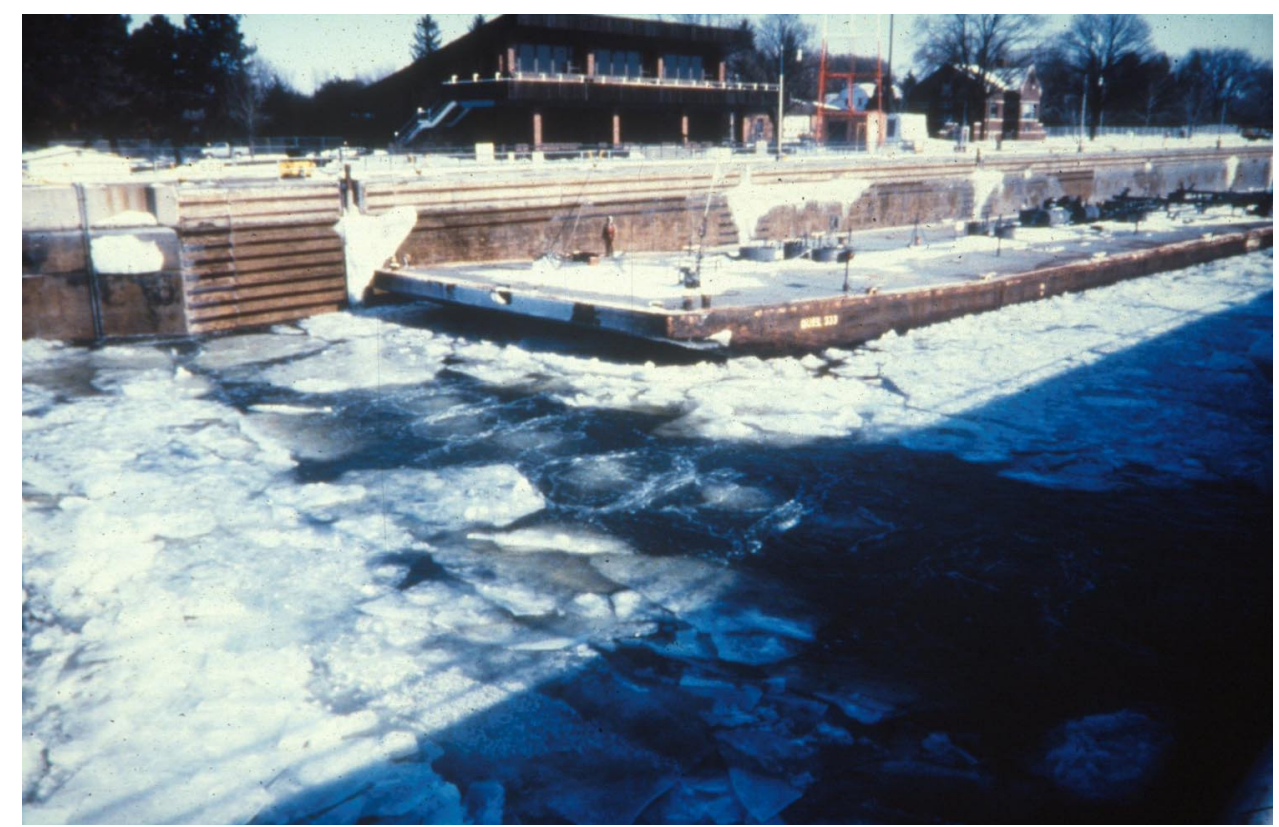

Figure 18. Lower sill curtain at Starved Rock Lock. 
use them. Ice suppression bubblers have not been successful in all circumstances. For example, in the miter gate recesses at Starved Rock Lock, in extreme cold weather, the agitation of the surface water exacerbated ice collar formation rather than inhibiting it.*

\section{Electric heaters}

Haynes et al. (1997) installed a 1.22-×2.44-m, 1920 $\mathrm{W}$ electric heater panel that successfully shed ice collars from the lower gate recess at Starved Rock Lock on the Illinois River. Plans were made to install panels along the entire 22-m length of the gate recess and cycle power from one panel to the next every 30 minutes to conserve power. The plan, though feasible, has not been carried out to date, perhaps because of a recent trend of mild winters on the Illinois River.

At Marseilles Lock, because of high water levels in the lock chamber, the lower miter gate strut arm recesses tend to ice up. Electric mat heaters developed

*Personal communication, Mark Witalka, Assistant Lockmaster, Starved Rock Lock and Dam, August 2000. by CRREL have largely solved this problem (Rand 1988). A number of other electric heat applications are detailed in Haynes et al. (1997).

\section{Low-adhesion panels}

High-density polyethylene panels were installed in the gate recess at Starved Rock Lock to help shed ice, but performance declined as the plastic aged and became more and more abraded. Also, ice tended to build up on the stainless steel bolt studs and washers used to install the panels. A newer type of panel made of ultrahigh molecular weight (UHMW) polyethylene, claimed to be more abrasion-resistant, is being tested in the gate recesses at Starved Rock.

\section{ICE-AFFECTED DAM COMPONENTS}

Dam gate ice problems (Table 2 and Fig. 1) are at least as troublesome as the ice problems encountered at locks. Also, unlike many northern locks that are closed to navigation during the most severe winter months, dam gates must be operated throughout the

Table 2. Ice-affected dam components and related issues.

\begin{tabular}{l} 
Dam component \\
\hline Tainter gates \\
Trunnion arms \\
Trusswork and enclosures \\
Lifting mechanisms, chains, \\
Side and bottom seals \\
\\
Submergible tainter gates \\
Direct lift gates \\
Roller gates \\
Pier walls \\
Gate sills \\
Downstream bed protection \\
Hydroelectric intakes \\
Electric heaters \\
Side and bottom seals \\
Side seal plate \\
Skin plate \\
Steam heat systems \\
Boilers \\
Portable hoses \\
Pnsulated piping systems \\
Peal leak prevention \\
Ashoppers
\end{tabular}

Ice issue

Arms freezing to pier walls

Spray ice buildup on trusswork

Icing and freezing-in of lifting mechanism

Leakage and freezing-in of seals

Large openings needed to pass ice

Allow ice skimming, vibration possible

Freezing of lifting chains

Submergible, prone to freezing-in

Ice buildup problems

Freezing-in

Downstream scour possible when passing ice with low tailwater

Frazil or brash ice blockages

Energy costs, corrosion of connections and elements Frequent maintenance and replacement

Personnel requirements, safety

Piping and easy hose connections

Freezing of condensate

Personnel requirements and safety 
winter to maintain pool heights. Other ice-affected dam components are dam sills, aprons, stilling basins, and downstream bed protection. Hydroelectric intakes also experience ice problems at many Corps dams. A number of electric heat solutions to dam ice problems (Haynes et al. 1997) have had varying levels of success. Steam and melting compounds are also used to deice dam gates.

The most common type of spillway gate is the tainter gate with its associated components: trunnion arms, skinplate assemblies and enclosures, hoisting mechanisms, chains and cables, as well as side and bottom seals. A subset of the tainter gate group is the submergible tainter gate, which can be lowered into a recess in the sill to allow flow of water and ice over the top. The large cylindrical roller gates found on the upper Mississippi can be raised for underflow or operated in submerged mode. Direct lift gates found on high superstructure dams on the Ohio River move up and down in vertical slots in the concrete pier walls.

\section{Tainter gates}

Tainter gates are the most common type of spillway gate found at Corps navigation projects because of their reasonable cost, simplicity, and light weight. Also, the side seal arrangement eliminates the need for recesses in the pier walls, avoiding energy losses. Their width ranges from about 40 to $110 \mathrm{ft}$ and height is typically between 10 and $20 \mathrm{ft}$. The front surface or skinplate assembly of a tainter gate attaches via trunnion arms or end frames to trunnions anchored in the concrete pier walls. Most tainter gates are raised by electric motors with lifting chains or cables to allow flow to pass beneath. Disadvantages of tainter gates are the long trunnion arms needed to raise the gate completely from the water during flood flows and ice runs and side seal leakage. A subset termed "submergible" or "submersible" gates, treated separately below, can be raised for underflow or lowered to allow flow to pass over the gate crest ("Submergible tainter gates"). Split leaf or "piggyback" gates found on Monongahela River dams consist of two tainter gates, one on top of the other. The top leaf can be raised clear of the water, allowing flow over the lower leaf, or the two gates can be raised as a unit to permit underflow.

Because the water flowing beneath a raised gate is under greater pressure, discharge is two to three times greater in raised mode than for an equivalent opening height for a gate in submerged mode. The higher flow capacity in underflow mode helps draw ice towards the gate, but a large gate opening is needed to draw the ice pieces beneath the gate. For example, an 8 -ft-high tainter gate must be raised 4 to $5 \mathrm{ft}$ in order to draw ice beneath. In a low tailwater situation, the large opening and concentrated discharge may result in damage to the downstream bed protection. This occurs because the width of the stilling basin and downstream bed protection are minimized for economic reasons, assuming that gate opening heights will be fairly even across the dam. As a result, at projects equipped with only underflow gates, it may not be possible to pass ice and adhere to the recommended gate schedule under low tailwater conditions.

Common tainter gate ice problems and related components (Table 2 and Fig. 2) include trunnion arms freezing to the concrete pier walls, spray ice buildup on the gate trusswork, icing and freezing-in of gate lifting chains, and leakage and freezing-in of side and bottom seals. The common solution is to periodically move the gates up and down or "cycle the gates." The usual frequency of this operation is once per eight-hour shift, but some operators prefer not to do it at night when visibility is poor and breakage of machinery possible. Often, simply releasing tension on the hoisting chains allows the gate to break free under its own weight without running the risk of overloading the lifting motors. If this fails, operators carefully apply tension to the hoisting mechanism in an effort to break the gate free.

If a gate is solidly frozen in, other methods such as chipping, steaming, electric resistance heaters, or the use of melting compounds such as rock salt become necessary. Manually chipping ice from gate components is still common at many projects. In addition to being arduous, this work is potentially dangerous, as personnel must get out on icy walkways, often above fast-flowing water. The solution is temporary at best because, due to seal leakage and spray icing, gates often refreeze just a few days after being chopped out (see below).

\section{Trunnion arms}

Tainter gate trunnion arms often freeze to adjacent pier walls as a result of spray icing and side seal leakage (Fig. 19). The clearance between the gate arm and the wall influences the severity of the problem. For example, at Starved Rock and Dresden Island Dams on the Illinois River, the clearance is only a few inches and the gate arm freezing problem is severe. Marseilles Dam, which lies between Dresden and Starved Rock, was retrofitted in 1989 with submergible tainter gates with the trunnion arms angled away from the pier walls (Fig. 20). The greater side clearance largely eliminated the freezing-in problem. Also, during cold periods, the gates are operated in the submerged mode, which eliminates spray icing and side seal freezing. On the upper Mississippi, the clearance between gate arms and the pier walls is about six inches and freezing-in is typically less of a problem than on the older gates on the Illinois River. 


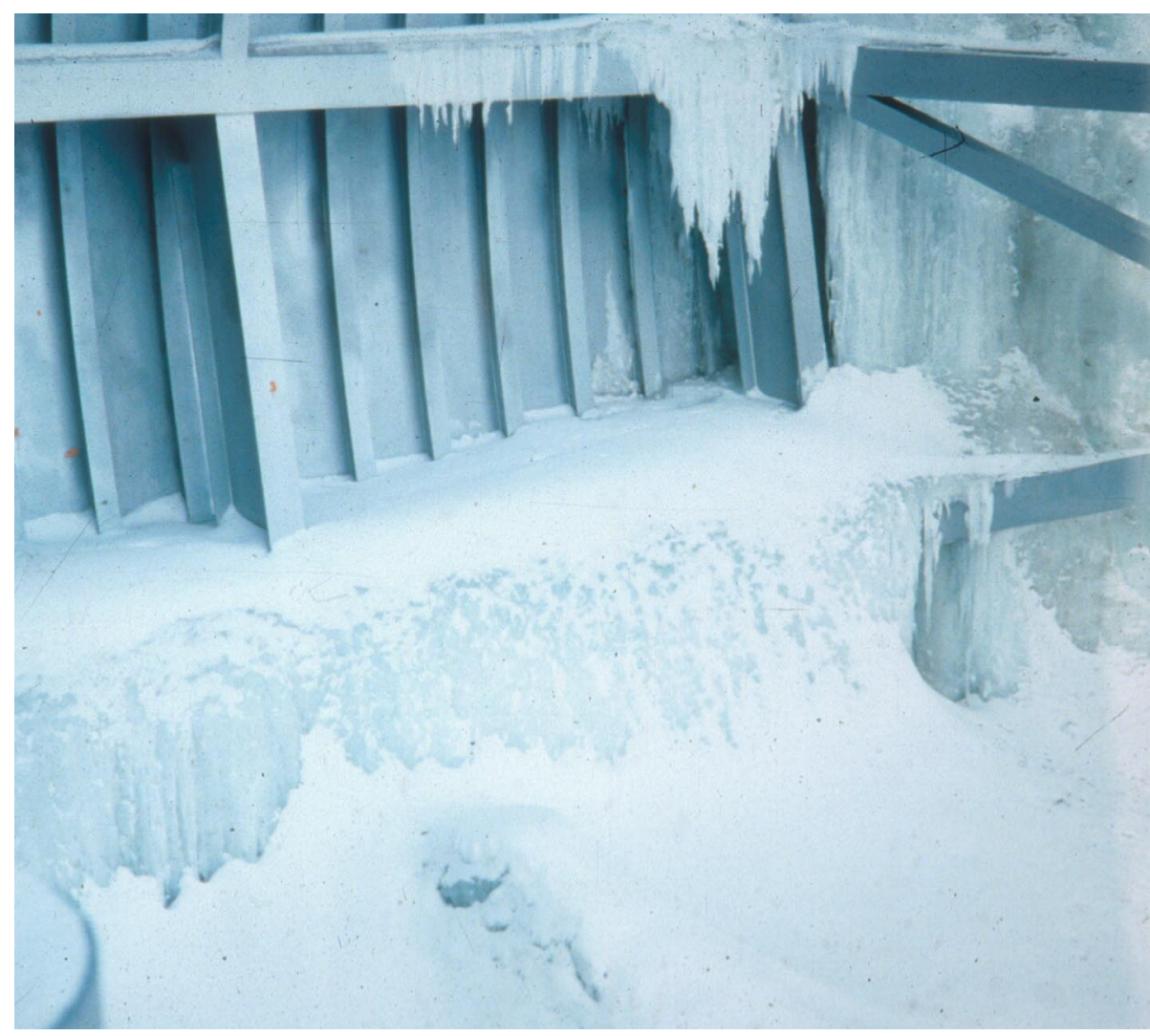

Figure 19. Iced-in tainter gate.

\section{Trusswork and enclosures}

Spray ice and seal leakage often lead to substantial ice buildups on gate structural members and trusswork (Fig. 19). In addition to freezing the gate in place, the weight of the accreted ice can overstress or exceed the capacity of the lifting mechanisms. Enclosing the gate trusswork with sheet metal reduces the ice buildup on gate structural components to some degree. At Starved Rock Dam two gates were enclosed and steam applied inside with only marginal ice-melting success.

\section{Lifting mechanisms, chains, and cables}

Icing and freezing-in of gate lifting mechanisms such as chains, cables, and cogs plague many Corps dams. On some of the older projects on the Illinois River, the gate arms are counterweighted to reduce the power requirements of the lifting motors.

The bicycle-type chains on the upper Mississippi that are particularly prone to icing problems are gradually being replaced with conventional link-type "logger" chains and pocket wheels that perform better in the cold, possibly because the links are bigger and looser.

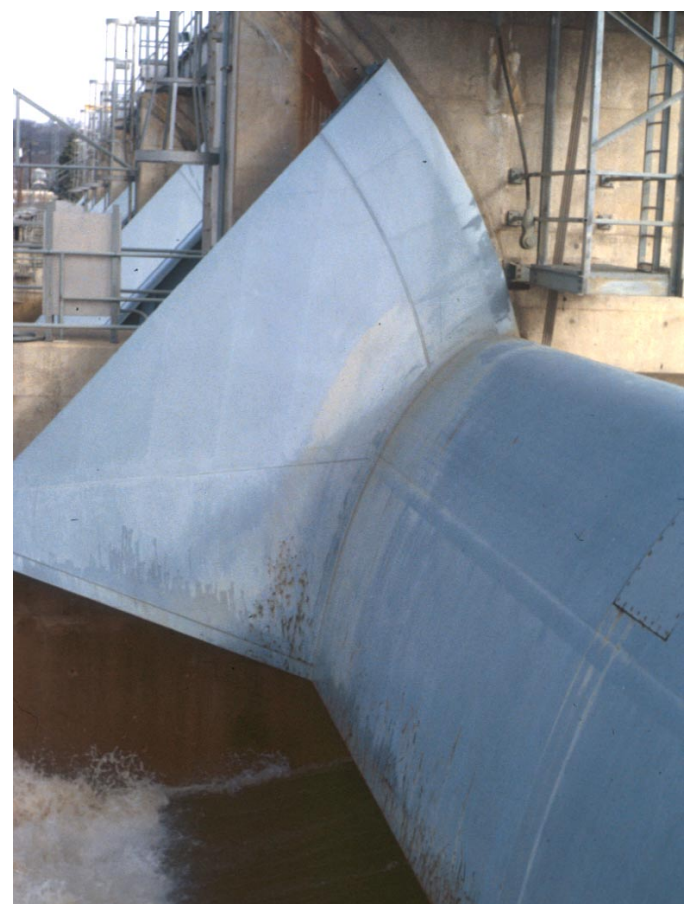

Figure 20. Submergible gate at Marseilles Dam. 


\section{Side and bottom seals}

The most common cause for gate freezing is leakage of side and bottom seals. The typical arrangement consists of rubber J-seals on the downstream sides of the gates that slide along a steel rub plate recessed into the concrete pier wall. Efforts to incorporate electric resistance heating into the steel rub plate or the J-seal itself have met some success ("Hydroelectric intakes"), but the moist environment makes periodic replacement of the heaters or heat trace necessary. A number of projects have opted for steam melting systems for their gate seals ("Electric heaters").

\section{Submergible tainter gates}

Advantages of submergible gates are the capability of skimming loose ice with a minimum amount of flow, and avoiding downstream scour. Also, submerged operation largely avoids the problem of freezing-in of side seals. Vibration of submerged gates has been a problem at many projects, particularly the 110 -ft-wide gates on the Ohio River. In some cases a retrofit to a sharpcrested bottom seal eliminated the problem (U.S. Army 1985), but at many other projects, particularly on the Ohio River, the submerged mode of operation was simply discontinued. It should be noted that, for maximizing flow to draw ice or debris towards a gate, underflow mode is preferable since capacity for a given opening height will be two to three times greater than in the submerged mode. Also, under conditions of heavy running ice or debris, projects on the upper Mississippi avoid the submerged mode because it could be difficult or impossible to re-raise the gates to stop the outflow.* Also, in cases of extreme ice and water discharge, the common practice is to raise the gates clear of the water to avoid damage. $\dagger$

\section{Direct lift gates}

Some of the 110-ft-wide gates on the upper Ohio River dams are "direct lift" with no gate arms and a flat front surface. The gates slide vertically in recesses in the concrete piers (Fig. 21). Because they are enclosed on both faces, icing of the direct lift gates trusswork is eliminated, but the direct lift gates do encounter some problems with icing of pier recesses and the lifting chains. At Montgomery Lock and Dam on the Ohio River, the lifting mechanisms are deiced using calcium chloride (Anderson 1998).

\footnotetext{
*Personal communication, Chris Morgan, Lockmaster, Lock 24, Mississippi River, August 2000.

$\dagger$ Personal communication, Jim Hart, Lockmaster, Marseilles Lock and Dam, August 2000.
}

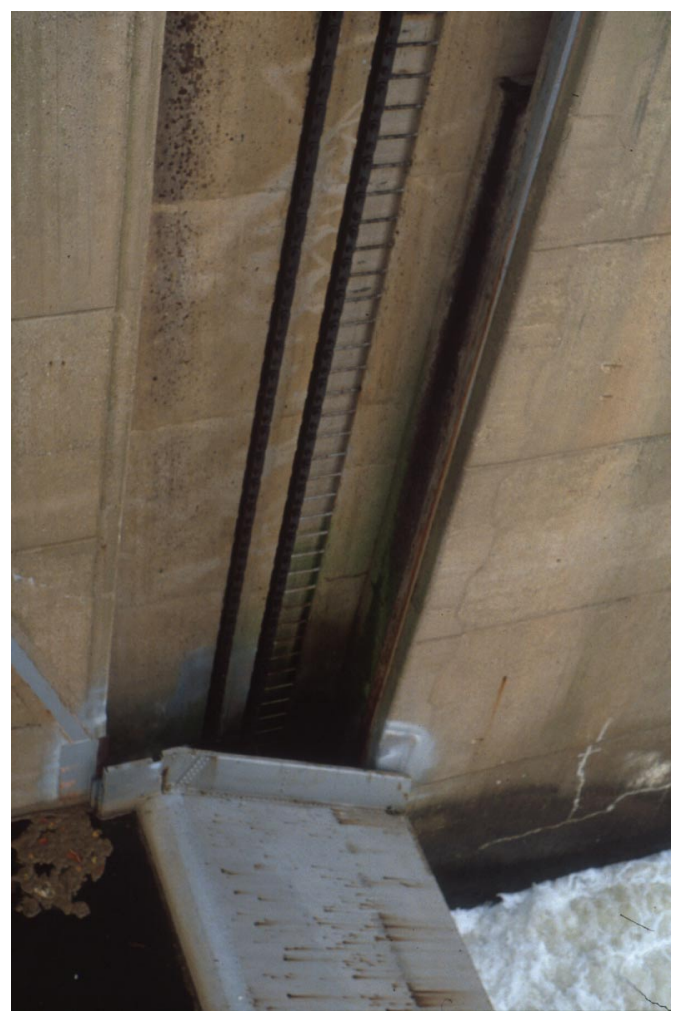

Figure 21. Direct lift gate at Montgomery Dam.

\section{Roller gates}

Roller gates are large-diameter cylinders that move up and down in cogged recesses to allow underflow or overflow. Roller gates can be up to $150 \mathrm{ft}$ long by $30 \mathrm{ft}$ high, but on the upper Mississippi they are typically 60 to $80 \mathrm{ft}$ wide. A typical arrangement is to have three or four centrally located roller gates, flanked by narrower tainter gates. A common practice is to set the roller gates a few feet below low pool level and allow them to freeze in for the winter. Adjustments in outflow are then made using the tainter gates. Operators at projects where the roller gates are moved in winter must combat spray icing of the gate recesses and the flanges at the ends of the gates. In some cases the icing is severe enough to actually bend the flanges out from the recesses. At many projects, designers anticipated this problem and cast electric heat elements in the concrete during the original construction, but these heaters have long since ceased to function and were never replaced. At Locks and Dams 10 and 16, special frames with infrared heat bulbs are lowered down the roller gate recess tracks to melt ice. These 220 -volt, 60 -amp heaters are described in Haynes et al. (1997). At Dams 16 and 14 on the upper Mississippi, freezing problems with their roller gate lifting chains have been remedied by replacing the lower 
links with stainless steel links. ${ }^{*}$ The fact that the stainless steel links have a lower adhesion to ice than rusted bare steel likely contributes to the improved performance.

The lower links of the sprocket chains on roller gates, also prone to freezing in, have been replaced with stainless steel links at a number of upper Mississippi River projects, including Dams 14 and 16.

\section{Pier walls}

Similar to gate trusswork and trunnion arms, significant ice builds up on gate pier walls, preventing gate movement. The problem is worse on north-facing walls that do not receive direct sunlight. Current solutions include chipping, steam, and, in a few cases, electric heat. To date, electric heat applications have been less than successful, however, Starved Rock Dam being a case in point. Here the heater elements were embedded directly in the pier walls in the early $1980 \mathrm{~s}$, and when they failed they never were replaced. $\dagger$ As mentioned in "Tainter gates," the pier wall icing presents the greatest problem when the clearance between the wall and the gate trunnion arm is small.

\section{Gate sills}

Gates also freeze in along their sills. Existing solutions include chiseling, steam, and electric heat. At Dresden Dam, electric heat trace along the bottom gate seals worked for a while, but ultimately failed and was not replaced. Personnel now chip the sill free manually, working from narrow walkways along the backs of the gates. The most efficient technique is to create a continuous fracture line in the ice along the sill and cause the ice to fall off in a single large piece. $\S$

\section{Gate skinplates}

Ice formation on gate skinplates, either from waves, wind-driven spray, or simply thermal cooling, can also prevent gate movement. Solutions include frequent cycling of the gates, electric heaters, and ice suppression bubblers. At Starved Rock Dam, pool elevation is regulated automatically by flow through the powerhouse and two tainter gates that are designated to pass any excess flow. Because they are moved infrequently the gates tend to ice in on their upstream sides. Project

\footnotetext{
*Personal communication, Jim Headley, Lockmaster, Lock and Dam 16, Mississippi River, August 2000.

$\dagger$ Personal communication, Mark Witalka, Assistant Lockmaster, Starved Rock Lock and Dam, August 2000.

§Personal communication, Roy Chapman, Lockmaster, Dresden Island Lock and Dam, January 1998.
}

operators and CRREL are experimenting with electric heated water jets to prevent ice from forming on the gate skinplates. At Dam 1 on the upper Mississippi, installing electric heat panels on the gate skinplates cured a similar icing problem, and low-flow point source bubblers are used to move warmer water from below (Haynes et al. 1997).

\section{Downstream bed protection}

To pass ice through tainter gates, many projects concentrate the flow through only one or two of their gates set at large openings. In many cases, downstream bed protection was not designed for this type of operation, however, and damage results, particularly under low tailwater conditions. A history of scour problems below its dams has led the Pittsburgh District to its current policy of designing downstream bed protection to withstand, without damage, the full range of possible gate outflows under any tailwater condition.*

\section{Hydroelectric intakes}

Icing of hydroelectric intakes is a major problem at both Corps and private sector generating facilities on northern U.S. rivers. Ice blockages of intakes and trashracks result from frazil ice during the ice formation period and from brash ice resulting from navigation activity or the natural breakup. A number of remedies exist, such as upstream booms to retain ice, or electrically heated trashracks to melt frazil (Daly 1991).

\section{Electric heaters}

Electric heat solutions to dam gate icing have been mentioned in previous sections and are well documented in Haynes et al. (1997). Included are heat trace inside $\mathrm{J}$-seals on gate sides and along tainter gate sills, heat elements built into side seal rub plates on the pier walls, and heater panels on gate skin plates. Negatives to electric resistance heat are energy costs, corrosion, and burnout problems associated with the wet environment. The experience with the heaters embedded in the pier walls at Starved Rock Dam illustrates the problem ("Roller gates").

At Dresden Island and Starved Rock Dam, $20 \mathrm{~W} / \mathrm{ft}$ heat trace was inserted in the hole of the J-seals on the sides of the tainter gates. At Dresden this worked well. At Starved Rock, where conditions are more severe, the single heat trace was insufficient to keep the side seal thawed and flexible, so a second trace was inserted

\footnotetext{
*Personal communication, Walt Leput, Chief, Hydraulics and Hydrology, Pittsburgh District, Pittsburgh, Pennsylvania, October 1998.
} 
in the J-seal hole. This resulted in burnouts and damage to the seals so the concept was abandoned in favor of steam deicing.

Almost any electric heat ice-melting application requires periodic replacement of heater elements. For this reason, it is critical that the heaters be easily accessible and replaceable. In many applications this has not been the case - for example, heaters were embedded directly in concrete pier walls at Starved Rock Dam. Once the elements failed they were typically not replaced and operators turned to other solutions such as chipping, steaming, or taking the gate out of service.

At Starved Rock Lock and Dam the City of Peru, Illinois, constructed a 30-MW hydro plant in 1995. As part of the lease agreement, the city agreed to provide the Corps project with free power, making the alternative of ice melting with electric heat much more attractive. Similar arrangements at other Corps dams with hydro plants (or those considering them) should be considered.

\section{Steam heat systems}

Steam heat systems at Corps projects range from very simple to quite sophisticated. The simplest systems consist of an oil-fired boiler and flexible hose to convey the steam to problem areas. Although effective, manpower requirements are high as people are needed to run the hoses and direct the steam lances to the problem areas. In some cases personnel must work in hazardous environments such as pier noses or icy walk- ways on or above the gates. Freezing of steam condensate in the uninsulated supply lines is another common problem associated with steam melting.

Starved Rock Dam is an example of a state-of-theart gate steaming system that requires very little manpower and is safe for personnel to operate. An automated, 500,000 BTU, oil-fired boiler supplies steam to the edges of each tainter gate via insulated six-inch trunk line along the service bridge. Only gates 1 and 2 are deiced at present. Four two-inch lines tee off from the trunk line to the sides of the first two gates, terminating in three-valve manifolds with one-inch camlock fittings (Fig. 22). One of the manifolds connects via flexible 1$1 / 2$-inch hose to a steam lance that runs behind the side $\mathrm{J}$-seal. This lance consists of a 1-1/4-inch stainless steel pipe with 1/4-inch holes spaced six inches apart. A halfinch stainless steel pipe inside the 1-1/4-inch pipe houses a heat trace to thaw out the lance before steaming. It turns out that simply having the smaller pipe as a drain is sufficient to keep the lance ice-free, and the heat trace is not essential. A second 1-1/2-inch hose goes from the second manifold valve to a tee-shaped lance made of one-inch steel pipe. An operator lowers the tee down the bulkhead wall to thaw the gate trunnion arm. Once in the desired position, the upper end of the tee is clamped to the railing, and the operator returns every 20 minutes or so to reposition it. To start the operation, the boiler is fired up and a third manifold valve is opened to the air to blow off wet steam and condensate. Once the steam is hot and dry it is di-

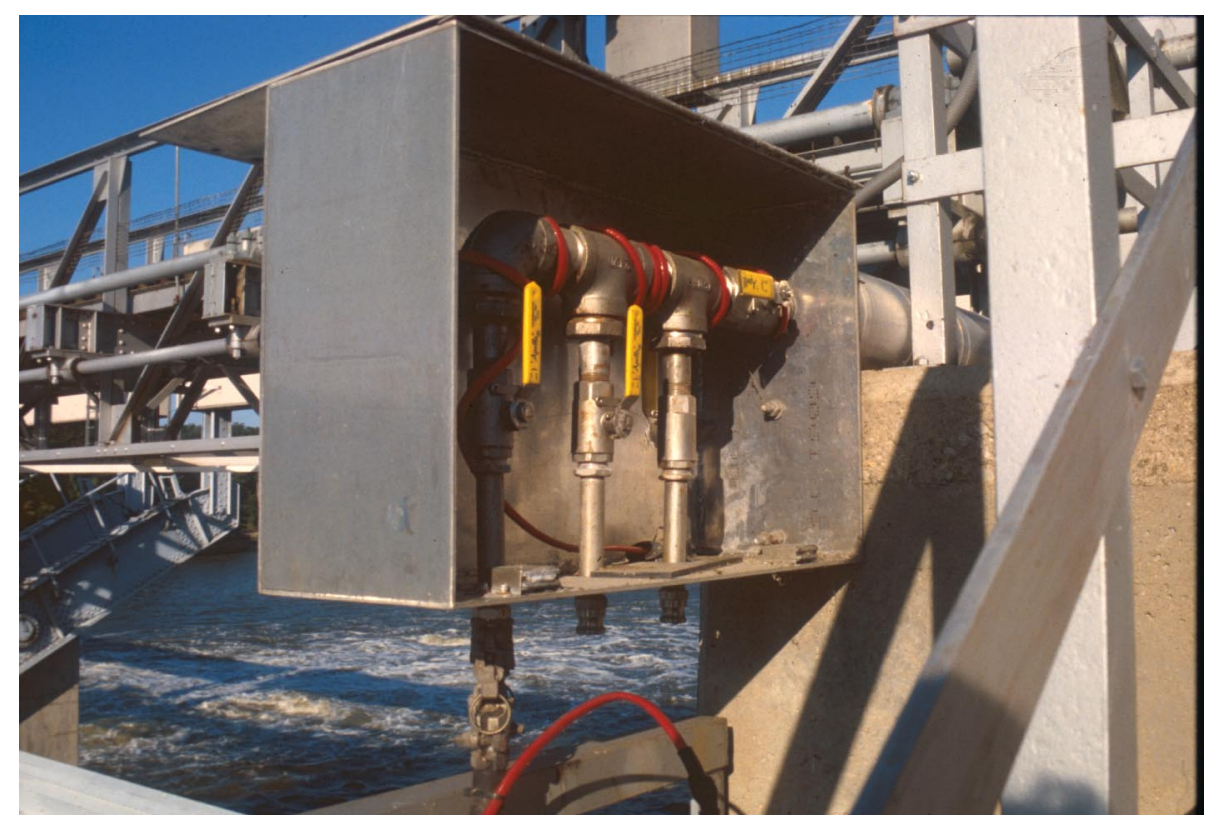

Figure 22. Steam manifold at Starved Rock Dam. 
rected to the lances and tees. In extreme cold, the boiler is set on low and the lances are supplied continuously. The entire operation can be done safely by one person, compared to the previous steaming system, which required four or five people, often in hazardous locations.

\section{Gate seal leak prevention}

One way to minimize gate side-seal icing is to reduce the leakage, either by improving the seal design or dropping fly ash into the water upstream of the seals. As the ash drifts downward, it is drawn into and plugs the leaks. Starved Rock operators have devised a simple but ingenious ash dispersal system consisting of hoppers and chutes to direct the ash from a safe location on the pier wall down to the water surface just in front of the seal. Not only does this improve personnel safety, but also it accomplishes the task with less material.

Minimizing gate leakage is also important for pool conservation during droughts and low-flow periods. At the 60-year-old Dam 24 on the Mississippi, leakage is a major problem because the submergible gate faces are dented and rubber bottom seals have long since been destroyed. During the drought of 1988, sand bags were dropped in the gap between the gate and the seal, an extremely labor-intensive process. Since 1989, the dents in the gate faces are being patched with steel plate and 2-1/2-inch angel steel welded horizontally to form a new seal with the gate sill.

\section{CONCLUSIONS AND RECOMMENDATIONS}

- Brash ice accumulation in the upper lock approach is the most serious ice problem faced by many projects and the cause of many other troubles such as ice congestion of the gate recess and lock chamber. The best existing solution is to continuously flush brash ice through an auxiliary lock chamber, or intermittently through the main chamber between vessel transits. This requires some type of overflow gate-either a vertical lift gate or emergency bulkheads - at the upstream end of the lock. The more common solution is still to lock the ice through, often delaying river traffic.

- Lock wall and miter gate recess icing remain as major problems at Corps projects. Low-adhesion coatings that are costly to apply only to wear off in a few years are not acceptable from an economic standpoint. Replaceable low-adhesion panels merit investigation. A plastic or composite panel system might be devised that sheds ice and, at the same time, reduces the frequency and costs of facial concrete rehabs, which are a major expense to the Corps.

- In general, submergible gates are less likely to freeze in place than underflow tainter gates when regu- lating pool height during low-flow periods in winter. This is because, being submerged, the seals do not freeze, and spray icing is eliminated. As a result, little manpower is needed to operate them and remote operation is possible, as at Marseilles Dam. Provided there is sufficient current in the pool upstream to draw the ice to the gate, a submergible gate can pass brash ice at much lower flows than an underflow gate. Also, increasing the clearance between the gate arm and the bulkhead reduces the tendency for the gate arm to freeze in place.

- To draw ice towards the dam and pass large volumes of ice, underflow may be preferable to submerged gate operation. Where this is the case, the bed protection downstream of one or two of the tainter gates should be designed to withstand the effects of large openings at low tailwater.

- All forms of electric resistance heaters - heat trace in seals, panel heaters on walls, etc. - should be designed to be easily replaceable with readily available, inexpensive components. Otherwise, the record shows that once they stop working, they will be abandoned.

- Steam melting systems should be designed to be energy-efficient and easily deployed with a minimum of manpower. Exposure of lock personnel to severe elements and hazardous situations should be minimized. Starved Rock Dam is an example of a state-of-the art steam deicing system that is efficient and safe to operate.

- The experience from the field (Mississippi River Lock 19) indicates that through-the-sill culvert intakes can be troublesome in term of ice congestion of the upper lock gates.

\section{LITERATURE CITED}

Daly, S.F. (1991) Frazil ice blockage of intake trashracks. Cold Regions Technical Digest No. 91-1, U.S. Army Cold Regions Research and Engineering Laboratory, Hanover, New Hampshire.

Davis, J.P. (1989) Hydraulic design of navigation locks. Miscellaneous Paper HL-89-5, U.S. Army Corps of Engineers, Department of the Army, Washington, DC. Frankenstein, G.E., and B. Hanamoto (1983) Methods of ice control. In ASCE state of practice report Design for Ice Forces. New York: American Society of Civil Engineers, p. 205-215.

Hanamoto, B. (1981) Ice control at navigation locks. In Proceedings, Water Forum '81, 10-14 August 1981, San Francisco, California. American Society of Civil Engineers, p. 1088-1095.

Haynes, F.D., R.B. Haehnel, and L.J. Zabilansky (1993) Ice control techniques at Corps projects. REMR 
Technical Report HY-14, Repair, Evaluation, Maintenance, and Rehabilitation Research Program. U.S. Army Corps of Engineers, Washington, DC.

Haynes, F.D., R.B. Haehnel, C. Clark, and L.J. Zabilansky (1997) Icing problems at Corps projects. REMR Technical Report HY-10, Repair, Evaluation, Maintenance, and Rehabilitation Research Program, U.S. Army Corps of Engineers, Washington, DC.

Rand, J.H. (1988) High-flow air screens reduce icerelated problems at navigation locks. In Proceedings, 9th International IAHR Ice Symposium on Ice, 23-27
August 1988, Sapporo, Japan, p. 34-43.

Sorrell, M. (2000) Mel Price Lock and Dam sets waterway standard. The Waterways Journal, 114(18): 7. U.S. Army (1985) Submergible gate use within the Corps. Case histories, Louisville District. U.S. Army Corps of Engineers, Louisville, Kentucky.

Zufelt, J.E., and D.J. Calkins (1985) Survey of ice problem areas in navigable waterways. CRREL Special Report 85-2, U.S. Army Cold Regions Research and Engineering Laboratory, Hanover, New Hampshire. 


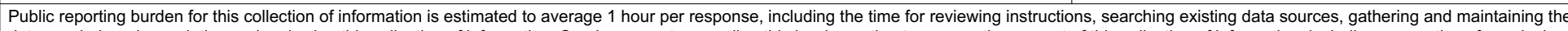

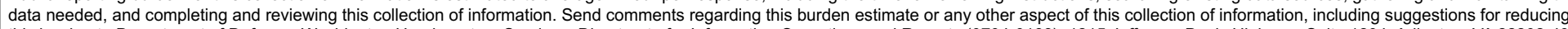

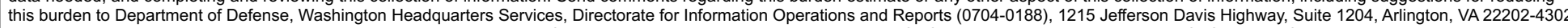

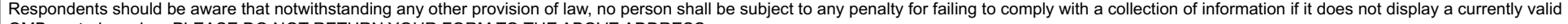
OMB control number. PLEASE DO NOT RETURN YOUR FORM TO THE ABOVE ADDRESS.
1. REPORT DATE (DD-MM-YY)
2. REPORT TYPE
February 2002
Technical Report
3. DATES COVERED (From - To)

4. TITLE AND SUBTITLE

Ice-Affected Components of Locks and Dams

5a. CONTRACT NUMBER

5b. GRANT NUMBER

5c. PROGRAM ELEMENT NUMBER

6. AUTHOR(S)

5d. PROJECT NUMBER

Andrew M. Tuthill

5e. TASK NUMBER

5f. WORK UNIT NUMBER

7. PERFORMING ORGANIZATION NAME(S) AND ADDRESS(ES)

8. PERFORMING ORGANIZATION REPORT NUMBER

U.S. Army Engineer Research and Development Center

Cold Regions Research and Engineering Laboratory

72 Lyme Road

Hanover, New Hampshire 03755-1290

ERDC/CRREL TR-02-4

9. SPONSORING/MONITORING AGENCY NAME(S) AND ADDRESS(ES)

10. SPONSOR / MONITOR'S ACRONYM(S)

Office of the Chief of Engineers

Washington, DC 20314

11. SPONSOR / MONITOR'S REPORT NUMBER(S)

\section{DISTRIBUTION / AVAILABILITY STATEMENT}

Approved for public release; distribution is unlimited.

Available from NTIS, Springfield, Virginia 22161.

13. SUPPLEMENTARY NOTES

14. ABSTRACT

Ice plagues the operation and maintenance of many U.S. Army Corps of Engineers locks and dams. Because these structures vary greatly in age, geographical setting, and design, their performance in ice also varies. This report describes the ice problems related to specific project components such as the lock approaches, miter gates, lock walls, and dam spillway gates. Post-construction solutions such as high-flow bubblers and heat deicing methods are also described. The report provides a one-source overview of the important ice problems faced by operators of Corps projects, available ice management solutions, and areas where improvements are most needed.

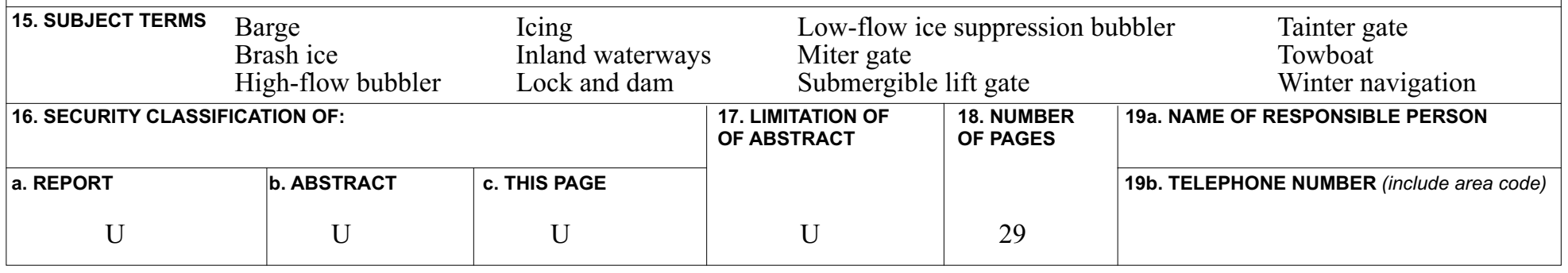




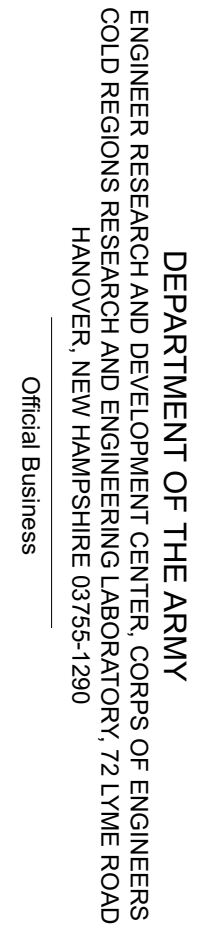

